\title{
NOŻE WOLUTOWE - O FUNKCJI I POCHODZENIU ZAGADKOWYCH PRZEDMIOTÓW W KULTURZE SŁOWIAŃSKIEJ
}

\author{
SPIRAL KNIVES: ABOUT THE FUNCTION AND THE ORIGIN \\ OF MYSTERIOUS OBJECTS IN THE SLAVIC CULTURE
}

\begin{abstract}
The text presents spiral knives, objects of clearly exceptional nature. The data, the map and table included here are meant to update information on the subject after 32 years. Identification of the specific regional groups and a metric analysis of the historical objects highlight the differences between the groups. The text also touches upon objects which are morphologically close to the spiral knives used by nomadic communities. A critical look at the theories in literature on the subject allowed to limit the functions to two, possibly mutually complementary.
\end{abstract}

Keywords: knives with spiral handles, the early Middle Ages, cult objects, nomads, pre-state period, material culture.

\section{WSTĘP}

Przedmiotem niniejszego opracowania są noże wolutowe, czyli specyficzna odmiana narzędzi, których zakończenie rękojeści zawinięte jest w charakterystyczne woluty. Wszystkie znane znaleziska tego rodzaju wykonane są z żelaza. Formowano je ze sztabek, które w wyniku rozkuwania przez kowala tworzyły długi prostokąt. Jedna część sztaby była przekuta w ostrze jednosieczne, druga część tworzyła rękojeść, jej górna część po rozgrzaniu była przecinana, a powstałe połówki zawijane w kształt woluty. Właśnie ta charakterystyczna cecha została wykorzystana do nadania nazwy tym przedmiotom. Proces przepoławiania widoczny jest na ich końcach dzięki obecności V-kształtnych odstępów pomiędzy wolutami. Rękojeści noży wolutowych, w przeciwieństwie do większości „zwykłych” noży, nie tworzyły trzpienia oraz nie były opatrzone w okładziny (a przynajmniej takowe się nie zachowały).

* ORCID 0000-0002-1312-522X, Instytut Archeologii, Uniwersytet Wrocławski, ul. Szewska 48, 50-138 Wrocław, e-mail: pawlickijk@gmail.com. 
Noże wolutowe nie należą do najczęstszych znalezisk na stanowiskach wczesnośredniowiecznych. Zespoły, w których występują, datuje się od VIII aż do początku X wieku. Ich obecność w materiale archeologicznym najczęściej wiązana jest z rolą kultu przedchrześcijańskiego jako narzędzi do składania ofiar. Mimo że są to znaleziska szczególne, nie cieszą się one należytą uwagą. Ostatnia publikacja na temat tej kategorii przedmiotów powstała 33 lata temu. Od tamtej pory doniesienia o nowych znaleziskach pojawiały się najczęściej jako kilkuzdaniowe informacje w monografiach stanowisk, na których je odkryto. Publikacje nie dostarczają odpowiednich danych o kontekstach ich odkrycia oraz powiązaniach stratygraficznych z innymi materiałami. Autorzy nie podają ich wartości metrycznych oraz nie publikują zdjęć zabytków czy rysunków po procesie konserwacji. Często w starszych pracach rysunki noży nie zawierają skali metrycznej, co uniemożliwia pozyskanie wymiarów zabytku, niepodanych wcześniej w tekście. Badacze określają wiek noży wolutowych na podstawie analogii do innych zabytków „szczególnych”, których datowanie także nie jest wiarygodnie przedstawione. Nader wymowny jest fakt, że na żadnym ze stanowisk wymienionych w niniejszym opracowaniu nie przeprowadzono datowań bezwzględnych obiektów, z których pochodziły noże wolutowe.

Niedostatek badań nad tą, jakże ciekawą, grupą zabytków skłania do przyjrzenia się ponownie zagadnieniu noży wolutowych. Na podstawie istniejącej już klasyfikacji tych przedmiotów (Korol'kova 1994) została stworzona ich nowa typologia. Oprócz zabytków zakwalifikowanych do noży wolutowych z terenów środkowoeuropejskich - zróżnicowanych w poszczególnych grupach - występują też przedmioty zbliżone do nich wyglądem na szerokich obszarach Eurazji. Dlatego skupiono się na prześledzeniu różnic i podobieństw w wyglądzie oraz kontekście występowania tej kategorii zabytków na poszczególnych terenach. Na tej podstawie podjęto próbę ustalenia genezy noży wolutowych w kulturze wczesnośredniowiecznych Słowian. Osobnym problemem jest funkcja tych przedmiotów. Opisane w literaturze koncepcje dotyczące ich zastosowania poddane zostały krytycznej analizie w celu ustalenia ich wiarygodności. Ostatnim, niezbyt twórczym, ale niezbędnym, aspektem podjętych studiów jest ponowne zebranie znalezisk noży wolutowych na podstawie publikacji z literatury europejskiej oraz euroazjatyckiej i uporządkowanie wiedzy z 72 lat badań nad tym tematem.

\section{HISTORIA BADAŃ NAD NOŻAMI WOLUTOWYMI}

Badania nad problemem noży wolutowych rozpoczęły się od odkrycia pierwszego tego rodzaju przedmiotu w 1947 roku na stanowisku wczesnośredniowiecznym w Biskupinie. Zdzisław Rajewski uważał, że nóż ten użytkowany był przez ludność scytyjską i datował go na VI wiek p.n.e. (Rajewski 1949, s. 54-55). Następnie w wyniku odkrycia noża wolutowego na cmentarzysku kultury przeworskiej 
w Gledzianówku Aleksander Gardawski przesuwa chronologię tych zabytków na okres wpływów rzymskich, popierając swoją hipotezę podobieństwem tych przedmiotów do noży z reliefu przedstawiającego stragan sprzedawcy z Rzymu (Gardawski 1952, s. 128). Kolejnym badaczem zagadnienia był Stanislav Šiška (1964), który stworzył pierwszy podział typologiczny bazujący jedynie na obecności ornamentu. Tematem tym zajmowali się między innymi: Rafail Minasân (1978), Wojciech Szymański (1964), Krzysztof Wachowski (1982) oraz Andrej Pleterski (1983). Ostatni z badaczy pierwszy przeprowadził badania metryczne owych znalezisk. Stworzył tabelę przedstawiającą długości i szerokości ostrzy oraz rękojeści, jednak nie porównywał tych danych w odniesieniu do różnych stref występowania noży wolutowych. W roku 1988 Wojciech Szymański w swojej drugiej publikacji na temat rzeczonej kategorii zabytków dokonał podsumowania wyników badań wyżej wymienionych badaczy (Szymański 1988).

Po roku 1988 zagadnieniem zajmował się również Viktor Kovalewskij, który przedstawił rysunki zabytków z terenów byłego Związku Radzieckiego oraz jego republik (Kovalewskij 1998, s. 12, ryc. 2), umożliwiając w ten sposób porównywanie cech morfologicznych noży $\mathrm{z}$ terenów zachodnich $\mathrm{z}$ okazami proweniencji wschodniej. W tym samym roku Ludmila Korol'kova na podstawie porównań przedmiotów opracowała swoją typologię, która bazowała na zakończeniach rękojeści i ukształtowaniu wolut. Następnym kluczowym etapem była praca Feliksa Biermanna (2001) dotycząca stanowiska Pennigsberg; w monografii tego stanowiska przedstawiono proces tworzenia noża wolutowego na podstawie wykonywanej repliki zabytku. Od niedawna zaczęły pojawiać się prace dotyczące występowania noży wolutowych na niewielkich obszarach; autorzy owych prac próbują odtworzyć zagadnienie obecności tego przedmiotu w społecznościach wczesnego średniowiecza. Powstałe prace omawiają znaleziska z Mołdawii (Rabinovič 2005), górnego Prutu oraz znad środkowego Dniestru (Mys'ko i Pivovarov 2010). Wart wspomnienia jest przykład monografii cmentarzyska w Thunau am Kamp pod redakcją Elisabeth Nowotny (2018), gdyż znajduje się tam jedyny wynik badań metalograficznych dotyczących noży wolutowych. Ów fakt rozmija się ze słowami Wojciecha Szymańskiego, który w 1988 roku zaznaczał, że to właśnie za pomocą specjalistycznych badań będzie można dokładniej zapoznać się z funkcją noży wolutowych.

Osobnym problemem jest chronologia występowania tego typu znalezisk. Początkowo po odkryciu noża z Biskupina oraz Gledzianówka przedmiotom tym przypisywano metrykę pradziejową lub z okresu wpływów rzymskich. W wyniku dalszych badań znalezione noże wolutowe datowano ramowo na okres od VI do IX wieku (n.e.). W literaturze polskiej powielano to datowanie, nie zwracając uwagi na korekty chronologii materiału ceramicznego grupy Tornow-Klenica, najczęściej towarzyszącego znaleziskom. Obecnie na całym obszarze występowania tych przedmiotów przyjmuje się datowanie od VIII do połowy X wieku. Do najwcześniejszego okresu ich występowania zalicza się okazy z terenów Kotliny Panońskiej, 
gdzie miały występować już od VIII wieku. Datowanie to powiązane jest z występowaniem owych zabytków na cmentarzyskach awarsko-słowiańskich, użytkowanych w ostatnim stuleciu funkcjonowania Kaganatu Awarskiego. Przykładem takiego stanowiska jest cmentarzysko w Thunau. Grób, w którym znaleziono nóż wolutowy, datowany jest na 2. połowę VIII wieku (Nowotny 2018, s. 162). Schyłkową granicę chronologiczną występowania noży wolutowych na terenie Europy Środkowej stanowią zespoły datowane na początek X wieku (tabele 7, 14). Problem datowania noży wolutowych w poszczególnych grupach zostanie omówiony w dalszej części tekstu.

Interesującym zjawiskiem jest obecność przedmiotów o podobnym kształcie na cmentarzyskach kurhanowych Bułgarów Wołżańsko-Kamskich, datowanych na VII wiek (Matveeva 1997). Galina Matveeva zajmująca się tą problematyką nie nazywa ich nożami wolutowymi, ale określa je jako szpile albo przedmioty sztyletopodobne.

\section{KLASYFIKACJA TERYTORIALNA I TYPOLOGICZNA NOŻY WOLUTOWYCH}

\section{Klasyfikacja terytorialna}

Analiza tego rodzaju przedmiotów byłaby niepełna bez poświęcenia należytej uwagi ich przestrzennemu rozmieszczeniu. Zamieszczona poniżej mapa (ryc. 1) ukazuje aktualny stan wiedzy autora na temat występowania noży wolutowych i przedmiotów zbliżonych do nich wyglądem. Na potrzeby pracy podział na siedem stref regionalnych stworzonych przez Wojciecha Szymańskiego (1988, s. 150-151) zostanie ograniczony do czterech zespołów i dwóch grup. Cechą wyróżniającą grupę od zespołu jest zasięg występowania noży wolutowych lub ich przedstawień w konkretnym mikroregionie w dużym oddaleniu od pozostałych zespołów. Strefa I wydzielona przez Wojciecha Szymańskiego $(1988$, s. 150-151) znajdowała się na terenie obecnych ziem polskich (tabele $2-5,8,10,12-13,15)$. Do drugiej strefy zostały zaliczone zabytki z terenu Kotliny Panońskiej (tabele 18-24, 26-27, 29-32). Strefa III składała się ze stanowisk pomiędzy Seretem a Dniestrem (tabele 36-39, 41-42, 47-49). Znaleziska z Bucov (tabela 34) oraz Garvan (tabela 35) zostały wydzielone do osobnej grupy - IV. Noże wolutowe znalezione na terenie stanowisk zlokalizowanych w środkowym biegu Dniepru pomiędzy Desną i jej dopływami a Worsklą włączone zostały do strefy V (tabele 44, 54). Strefa VI obejmuje region pomiędzy Dźwiną a Prypecią oraz górny bieg Dniestru (tabele 55-59, 63, 65). Do strefy VII Wojciech Szymański zaliczył jedynie zabytek z Grigorova (tabela 60). Najdalej wysuniętym na wschód miejscem, gdzie odkryto nóż wolutowy, jest stanowisko Siemiluki. Zachodnią granicę występowania tych zabytków wyznacza znalezisko w grodzie Pennigsberg w Mittenwalden (Brandenburgia) (Biermann 


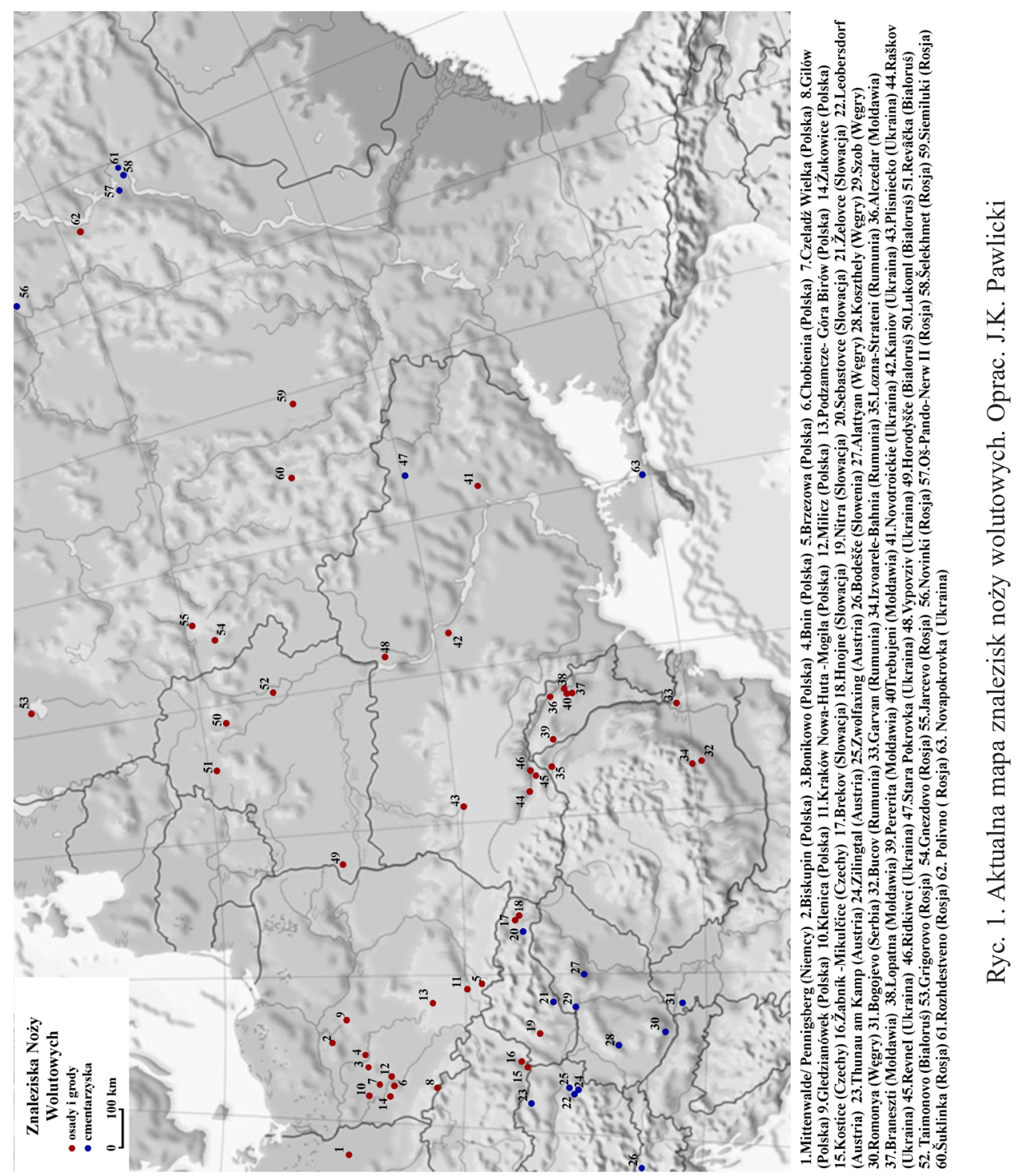


2001) - jest to obecnie jedyny egzemplarz znaleziony przez archeologów ${ }^{1}$ na zachód od Odry. Stanowiskiem najbardziej wysuniętym na północ jest nóż wolutowy z Grigorova nad jeziorem Ilmen. Południowy zasięg wyznacza znalezisko z dzisiejszej miejscowości Bucov w Rumunii.

\section{Założenia klasyfikacji typologicznej}

Autorzy publikacji opisujący egzemplarze z terenów dzisiejszej Ukrainy (Mys'ko i Pivovarov 2010, s. 312), Białorusi oraz Rosji korzystają z typologii zaproponowanej przez Ludmilę Korol'kovą (1994, s. 236, ryc. 2). Autorka dzieli noże wolutowe na kilka wariantów z przypisaną chronologią, tworząc podtypy jedynie na podstawie przecięcia górnej części rękojeści. Ten element związany jest raczej ze starannością wykonania egzemplarzy, a nie jest ich cechą charakterystyczną. Problematyczną kwestią jest sposób przerysowania wolut z zakończeń rękojeści, która jest nieczytelna dla niektórych zabytków. Noże wolutowe przypisane do typu pierwszego charakteryzuje zamknięta woluta nazywana przez autorkę ,wolutową płytką”. Zabytki typu drugiego charakteryzują się zakończeniem w typie „baranich rogów”. Wariant szósty typu drugiego nazwany został „S-kształtnym” przez głębokie nacięcie wnętrza rękojeści oraz wygięcie przeciętych końców na kształt litery S.

Typologia stworzona na potrzeby niniejszego opracowania opiera się na podobnych zasadach; nie będzie jednak poruszała kwestii chronologicznej. Zabytki zostały podzielone na cztery typy (ryc. 2). Do zbioru egzemplarzy z ,wolutową płytką" - typ I - należy zaliczyć przedmioty o zakończeniach, których woluty zawinięte są jeden raz i nie tworzą pełnej spirali. Typ II charakteryzuje się obecnością spirali, czyli kilkukrotnego zawinięcia przeciętej części rękojeści, przypominającego kształt „baranich rogów”. Wydzielono również pozostałe charakterystyczne zakończenia nie jako warianty, a typy; między innymi typ III wyróżniający się odwróceniem woluty i uformowaniem jej w kształt serca. Wojciech Szymański (1988, s. 143, przypis 7) nie zaliczał jedynego znanego mu egzemplarza z takim zakończeniem za nóż wolutowy, traktował go raczej jako wyjątek. Obecnie w literaturze austriackiej ten typ nazywany jest zakończeniem w kształcie serca i uważany jest za zakończenie noża wolutowego (Nowotny 2018, s. 103). Aktualnie znane są dwa zabytki należące do typu III, zlokalizowane w tej samej grupie regionalnej (tabele 25,28 ). Według wcześniej prezentowanej klasyfikacji należałyby one do wariantu 5. Typ IV to wydzielony przez Ludmilę Korol'kową wariant 6 typu 2 - zakończenie S-kształtne, które również można uznać za cechę regionalną obecną tylko w zespole północnym. Takie zwieńczenia

${ }_{1}$ Znalezisko z aukcji internetowej: https://auction.catawiki.com/kavels/18404209-medieval-medical-instrument-scalpel-lancet-rare-150-mm [dostęp: 16.05.2020]. Autor aukcji określa pochodzenie zabytku na Europę Północną, a posiadanie zabytku motywuje wyprzedażą prywatnej niemieckiej kolekcji sprzed lat 70. XX wieku. 


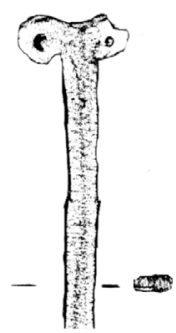

TYP

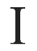

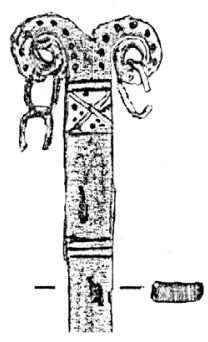

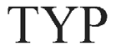

II

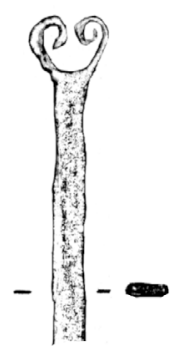

TYP

III

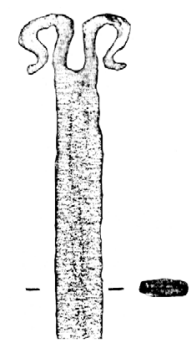

TYP

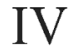

Ryc. 2. Klasyfikacja bazująca na wcześniejszych ustaleniach z wydzieleniem zakończeń rękojeści „w kształcie serca” oraz „w kształcie litery S”. Oprac. J.K. Pawlicki

rękojeści cechowały między innymi egzemplarze z Revâčki, Gniezdova i Jarceva (tabele 55, 61, 63).

Podział typów na warianty nie powstał, ponieważ widoczne na zabytkach ślady technologiczne po przecięciu górnej części rękojeści nie stanowią cechy wyróżniającej, a świadczą raczej o staranności wykonania. Noże z wielopoziomową wolutą (tabele 9, 74) oraz okaz ze specyficzną zaokrągloną końcówką rękojeści (tabela 16) nie znalazły się w typologii ze względu na ich niepowtarzalny charakter.

\section{WYNIKI ANALIZY METRYCZNEJ ZABYTKÓW}

Różnice wśród egzemplarzy przejawiają się nie tylko w formie ukształtowania wolut, ale i w wymiarach samych noży. Aby pozyskać potrzebne dane do analizy, wybrano jedynie zabytki kompletnie zachowane, których rozmiar podany był w tekście lub był możliwy do odczytania z rycin.

Typ I reprezentują zabytki o długości od 11,6 cm do 19,2 cm z większością zabytków w przedziale 17-18,6 centymetrów. Jednak zabytki, które nie są w pełni zachowane, a ich uszkodzenia można zrekonstruować, znajdowałyby się w przedziale od 14-15 cm. Kolejnym parametrem poddanym analizie była szerokość rękojeści w przypadku typu I mieszcząca się w zakresie 0,5-1,9 centymetra. Jednak większość rękojeści znajdowało się w zakresie 0,8-1,3 cm. Przedział długości przedmiotów typu II wynosił od 12,6 cm do 18,7 cm z większością zabytków o długości 17-18,7 cm. Szerokość rękojeści noży z tej grupy mieści się w zakresie 0,5-1,2 cm; najczęściej wynosiła ona 0,9-1 cm. Typ III reprezentowany jest przez 
jeden kompletny zabytek o długości 15,1 cm; w drugim egzemplarzu nie zachowało się ostrze, które stanowiło najpewniej jedną trzecią długości noża wolutowego; ich rękojeści są szerokie na $0,65 \mathrm{~cm}$ i $0,9 \mathrm{~cm}$. Długość noży typu IV znajduje się w zakresie 13,7-15,6 cm. Natomiast szerokość rękojeści tych przedmiotów to $0,9-1,4 \mathrm{~cm}$. Na podstawie uwidocznionych różnic wewnątrz określonych typów niemożliwe jest stworzenie klasyfikacji opierającej się na danych metrycznych. Zróżnicowanie metryczne wynika prawdopodobnie z kryterium geograficznego, a nie typologicznego. W dalszej części pracy przedstawione zostaną analizy metryczne zabytków z poszczególnych zespołów.

\section{CHARAKTERYSTYKA NOŻY WOLUTOWYCH \\ Z UWZGLĘDNIENIEM STREF WYSTĘPOWANIA}

\section{Zespół zachodni}

Do zespołu zachodniego przypisane zostały zabytki zlokalizowane pomiędzy Odrą a Wisłą, które odpowiadają grupie $\mathrm{I}^{2}$. Zespół zachodni (ryc. 3) reprezentowany jest przez 16 noży wolutowych. Analiza możliwa jest jedynie dla 14 egzemplarzy, w tym tylko siedem z nich jest w pełni zachowanych. Do zespołu należy część przedmiotów zaliczonych przez Stanisława Šiške (1964) do typu A - noży, na których znajduje się ornament. Problem obecności lub braku motywu zdobniczego w dużej części wynika ze stanu zachowania zabytków. Dominująca część noży w każdym zespole została opublikowana przed podjęciem prac konserwacyjnych, a więc oparcie klasyfikacji na podstawie występowania zdobień jest błędnym założeniem. Obserwacja obecności wątku zdobniczego pozwala na stwierdzenie, że wyznacza on zasięg rękojeści. Oprócz egzemplarza z Czeladzi Wielkiej (ryc. 3.7), gdzie ornament występuje również na ostrzu, charakter zdobień jest powtarzalny, manifestuje się poprzez obecność kresek, kropek oraz nacięć w kształcie jodełki. Zabytki pozbawione dekoracji reprezentują większą część grupy ${ }^{3}$. W zawinięciach wolut niektórych noży znajdują się pojedyncze ogniwa łańcuszka (tabele 2, 13) służącego prawdopodobnie do zawieszania przedmiotu przy pasie.

Zabytek odkryty podczas badań na stanowisku w Gilowie wyróżnia się na tle innych znalezisk o charakterze słowiańskim. Jego wyjątkowość wynika z obecności dwóch pięter wolut. Podobny przedmiot jest obecny na przedstawieniu z rzeźby kamiennej z terenu Kotliny Minusińkiej (tabela 74); podobieństwo jest raczej przypadkowe ze względu na oddalenie geograficzne obydwu regionów.

\footnotetext{
2 Podział zabytków na grupy według Wojciecha Szymańskiego (1988), stosowany też w dalszej części tekstu.

3 Do nich należy nóż wystawiony na aukcji internetowej https://auction.catawiki.com/kavels/ 18404209-medieval-medical-instrument-scalpel-lancet-rare-150-mm [dostęp: 16.05.2020].
} 

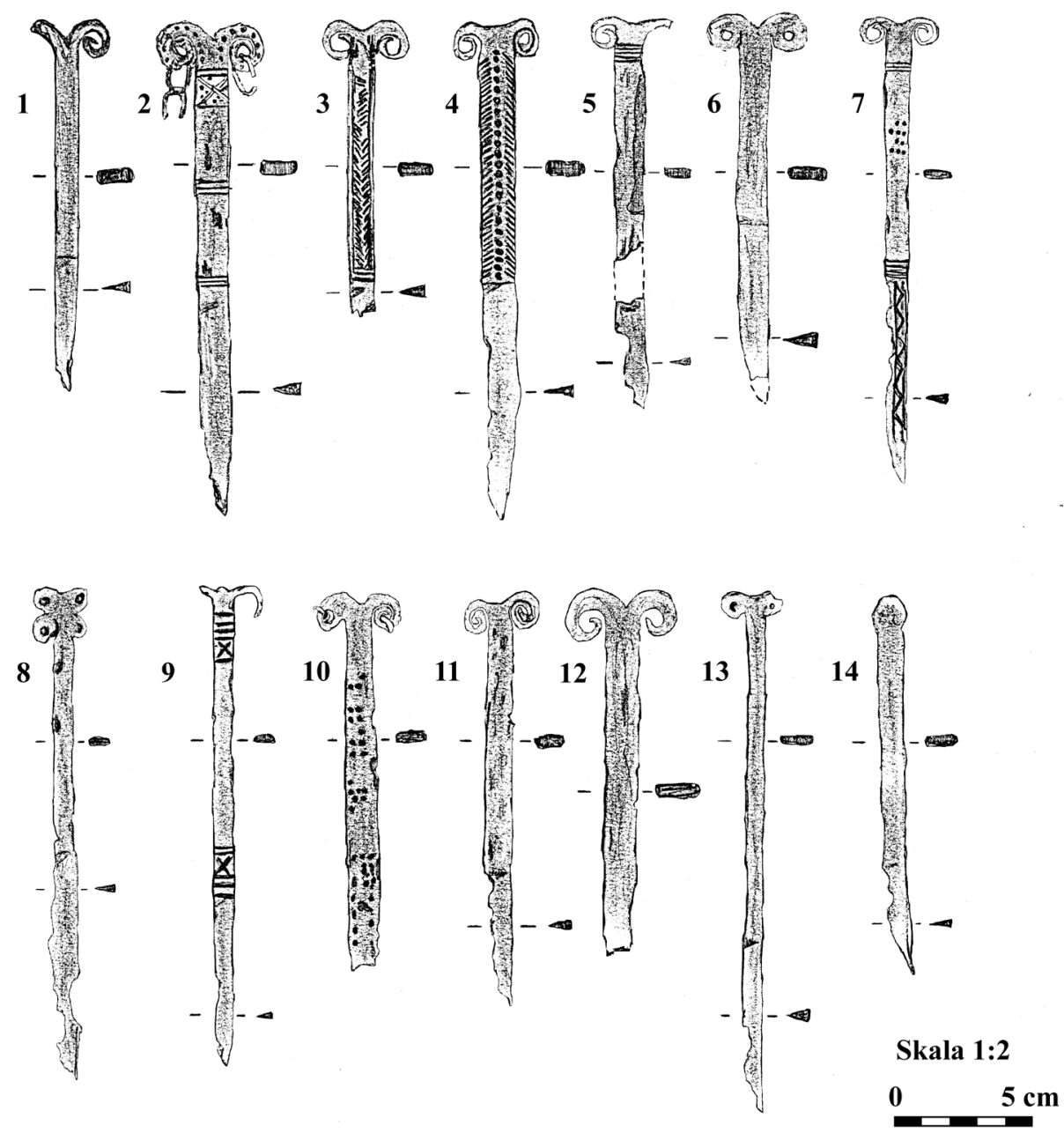

Ryc. 3. Noże wolutowe należące do zespołu zachodniego:

1 - Pennigsberg; 2-3 - Biskupin; 4 - Bonikowo; 5 - Bnin; 6 - Chobienia; 7 - Czeladź Wielka; 8 - Gilów; 9 - Gledzianówek; 10 - Milicz; 11 - Kraków-Nowa Huta; 12 - Podzamcze-Góra Birów; 13-14 - Żukowice. Rys. J.K. Pawlicki

Interesującą cechą zespołu zachodniego jest występowanie par zabytków na stanowisku w Biskupinie i Żukowicach (tabele 2, 3, 15, 16). Zabytki te nie należały do tych samych obiektów, a wystąpiły w innych częściach stanowisk. Obecność dwóch egzemplarzy na tym samym stanowisku wydaje się zaskakująca $\mathrm{z}$ racji ich unikatowości. Jeden $\mathrm{z}$ okazów z Żukowic pozostaje poza ustalonymi systemami klasyfikacji ze względu na brak rozcięcia rękojeści (ryc. 3.14). Niewykonanie tego procesu produkcyjnego może świadczyć o tym, że jest to niedokończony wytwór. 
Noże tego zespołu odnajdywane były w jamach lub warstwach osadniczych i nie stanowiły zawartości depozytów żelaznych albo depozytów grobowych, oprócz problematycznego znaleziska z Gledzianówka, które - jak stwierdzono po przeanalizowaniu planów wykopaliskowych przez Wojciecha Szymańskiego - nie znajdowało się w jamie grobowej, ale w warstwie ponad nią (Szymański 1988, s. 152). Pierwsze próby korekty chronologii grobu z Gledzianówka przedstawiał Konrad Jażdżewski, datując nóż na wiek VI (Jażdżewski 1960, s. 75-76).

Zabytki datowane są na okres od końca VIII wieku na stanowiskach takich, jak Brzezowa czy Żukowice, oraz w większości stanowisk do połowy wieku IX.

Noże wolutowe na terenie Polski mogą, przynajmniej w niektórych przypadkach, mieć genezę południową. Wskazują na to między innymi dość duże podobieństwa w formie wykonania egzemplarzy z podkrakowskiej Nowej Huty-Mogiły i słowackiego Hnojne. Kolejnym argumentem przemawiającym za tą strefą wpływu jest obecność materiału o charakterze południowym w Brzezowej (Ginalski i Muzyczuk 1989, s. 221). Autorzy badań zauważają też podobieństwa noża wolutowego z tego stanowiska do znalezisk z terenów obecnej Słowacji (Ginalski i Muzyczuk 1989, s. 228).

Długość zachowanych egzemplarzy zespołu zachodniego plasuje się w granicach pomiędzy $17 \mathrm{~cm}$ a 19,2 cm. Szerokość rękojeści możliwa jest do zmierzenia na każdym zabytku i wpisuje się w zakres od $0,9 \mathrm{~cm}$ do $1,2 \mathrm{~cm}$.

\section{Zespół południowy}

Południową strefę występowania zabytków tego zespołu wyznacza teren Kotliny Panońskiej, wpisując się w zasięg grupy II (Szymański 1988). W strefie południowej (ryc. 4) odkryto 16 egzemplarzy, jednak ze względu na stan zachowania do analizy nadaje się tylko połowa z nich. Charakterystyczną cechą tego ugrupowania jest kontekst znalezisk. Znaczna część noży została odnaleziona na tzw. cmentarzyskach awarsko-słowiańskich w grobach szkieletowych. Pochówki, w których wystąpiły takie znaleziska, nie wyróżniały się szczególnie pod względem darów grobowych.

Interesującą cechą nie okazało się wyposażenie grobowe, ale ciała złożone do grobów. Badania antropologiczne wykazały, że najczęściej pochowane z nożami wolutowymi były osoby młode, w wieku Infans II (6-12 lat) (Nowotny 2018, s. 102), oraz osoby płci żeńskiej (Daim 1987, s. 268). Jamy grobowe (ryc. 5), w których znajdowały się noże wolutowe, nie zawierały elementów charakterystycznych dla grobów awarskich, czyli okuć pasów czy ceramiki awarskiej. Mamy w nich raczej do czynienia z ubogim inwentarzem (Szymański 1988, s. 155). W przyszłości przydatne byłoby stworzenie zestawienia wyposażenia w grobach, w których jeden z elementów stanowił nóż wolutowy. 

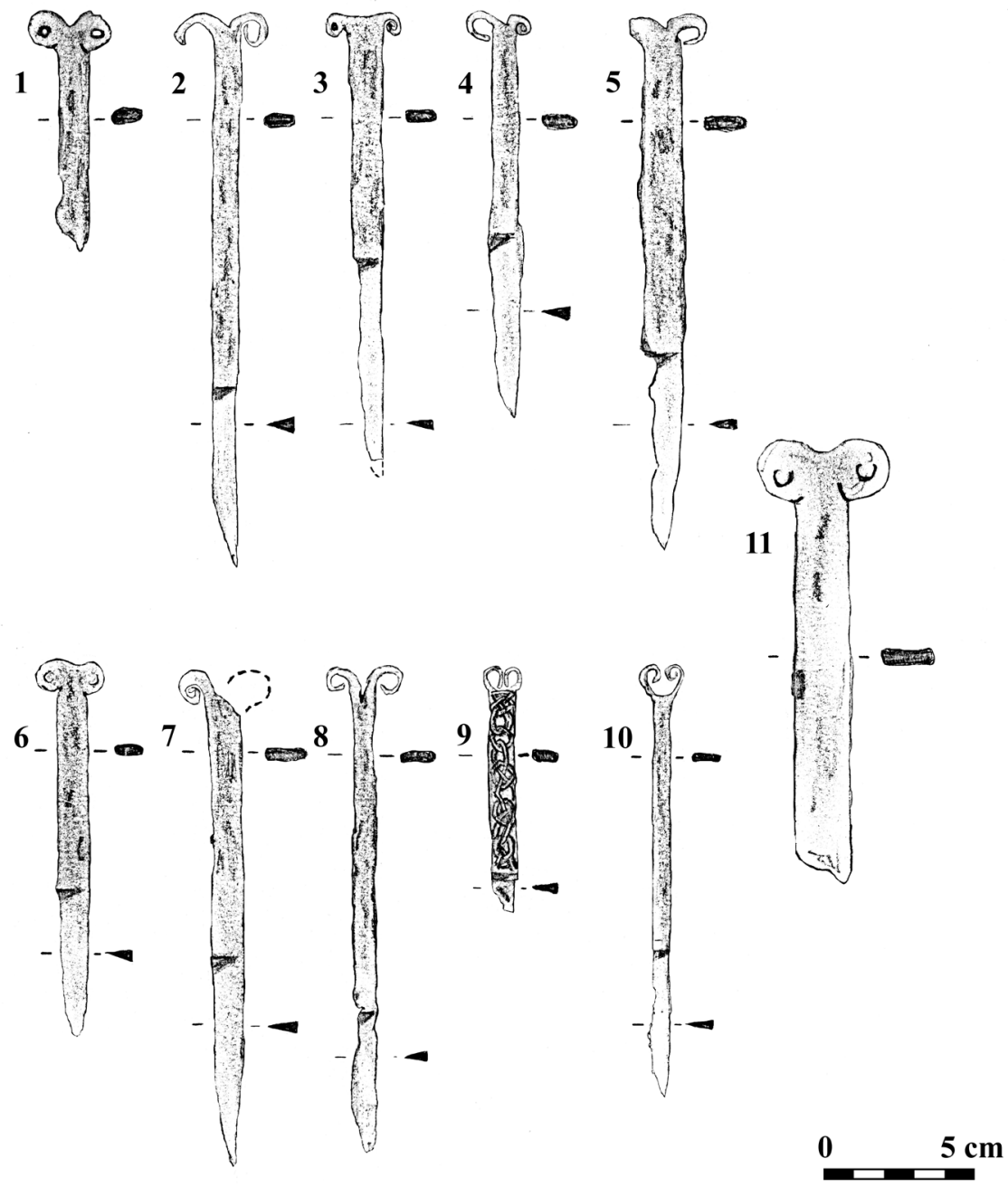

Ryc. 4. Noże wolutowe reprezentujące zespół południowy: 1 - Kostice; 2 - Žabník; 3 - Hnojne; 4 - Nitra; 5 - Želovce; 6 - Leobersdorf; 7 - Alattyan; 8 - Zilingtal; 9 - Bodešče; 10 - Thunau am Kamp; 11 - Szob. Rys. J.K. Pawlicki

Kolejną charakterystyczną cechą tej grupy są zabytki z modyfikacją woluty, tzw. noże z rękojeścią w kształcie serca (Nowotny 2018, s. 103) (ryc. 4.9 oraz 4.10). Należy do nich też zabytek z ornamentem odkryty na stanowisku Bodešče (Knific i Pleterski 1981). Podobnie jak w przypadku noży z zespołu zachodniego, zasięg zdobienia wyznacza początek rękojeści. Rękojeść tego noża pokryta jest ornamentem plecionkowym. Motyw ten przetrwał w sztuce słowiańskiej, między innymi na zdobieniach architektonicznych pierwszych obiektów religii chrześcijańskiej 

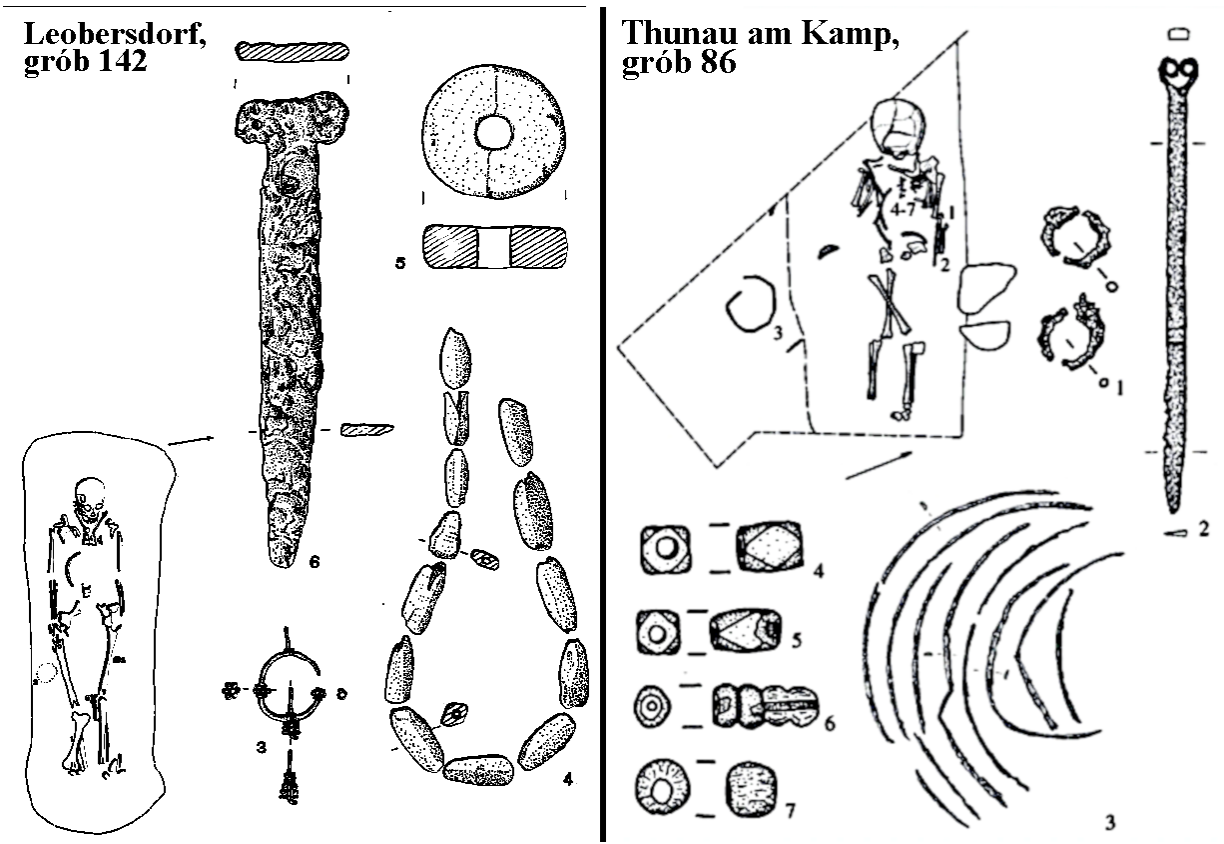

Ryc. 5. Zestawienie wyposażenia jam grobowych zawierających noże wolutowe, grób 142 z Leobersdorf (za F. Daim 1987) oraz grób 86 z Thunau (za E. Nowotny 2018)

u Słowian południowych. Zdobienie może też być imitacją łańcuszka, którego ogniwa znajdowane są w zawinięciach wolut innych noży. Większość zabytków z tego zbioru występowała na cmentarzyskach awarsko-słowiańskich.

Chronologia części tych stanowisk przypada na drugą połowę VII wieku lub od drugiej połowy VIII do IX wieku, tak też datowane są noże wolutowe (por. tabele 19, 22-24, 27, 29-32). W obrębie tej grupy występują też pojedyncze egzemplarze o późnej chronologii. Takie okazy pochodzą z Žabníka pod Mikulčicami (Bartošková 2007, s. 708) (tabela 18) i Kostic położonych niedaleko Břeclaví (Biermann, Macháček i Schopper 2015, s. 111) (tabela 17). Noże z tych stanowisk datowane są na fazę powielkomorawską (X wiek). Chronologia ta została ustalona na podstawie konkretnych cech ceramiki (Žabník, Kostice) i zbioru numizmatów (Kostice), jest więc dość pewna. Widoczna jest znikoma liczba noży wolutowych na stanowiskach wielkomorawskich, co potwierdza teorię Krzysztofa Wachowskiego o braku przeniesienia idei noży wolutowych przez państwo wielkomorawskie na tereny obecnej Polski (Wachowski 1981, s. 166).

Luka chronologiczna pomiędzy występowaniem noży na stanowiskach ,awaro-słowiańskich" i najmłodszymi przykładami tych przedmiotów w zespole południowym może być jednak pozorna. Nowsze znaleziska (Thunau am Kamp - tabela 25) oraz datowania niektórych stanowisk ramowo na VIII-IX (tabele 24, 31), 
IX (tabela 21), czy nawet IX-X wiek (tabela 20) albo VIII -XI (tabela 26) wskazują na ich użytkowane nieprzerwanie w IX do X wieku włącznie. Pojawiają się one także na pojedynczych stanowiskach kręgu wielkomorawskiego (Nitra, Thunau am Kamp).

Długość zachowanych zabytków wpisuje się w granicę pomiędzy $12,7 \mathrm{~cm}$ a $26 \mathrm{~cm}$, najczęściej są to noże o długości 17,5 cm. Szerokość rękojeści wpisuje się w zakres od 1,1 cm do 1,9 cm. W tej grupie występują noże o mniejszych rozmiarach niż w zespole zachodnim, ale o szerszej rękojeści.

\section{Zespół wschodni}

Zbiór wschodni występuje na terenie rozciągającym się od Niziny Wołoskiej, obejmując tereny pomiędzy Prutem a Dniestrem aż po region środkowego Dniepru, odpowiadając grupom III, IV i V (Szymański 1988). Zespół ten składa się z 20 egzemplarzy (ryc. 6), ale tylko siedem noży zachowanych jest w stanie pozwalającym na poddanie ich analizie. Dominująca część znalezisk znajduje się pomiędzy Dniestrem a Prutem, pozostałe noże odkryto na terenie obecnej Rumunii oraz nad środkowym Dnieprem na stanowiskach osadniczych. Okazy z terenów Mołdawii poddane analizie w ramach towarzyszącego im kontekstu kulturowego badanego przez Romana Rabinoviča (2005, s. 355) wskazują, że zostały one sprowadzone na tereny pomiędzy Dniestrem a Prutem przez ludność słowiańską przemieszczającą się z terenów Kaganatu Awarskiego. Powodem migracji miał być rzekomy ucisk ze strony awarskiej na początku wieku VIII.

Niektóre egzemplarze tej grupy przejawiają pewne odstępstwa od klasycznego wyglądu noża wolutowego. Na przykład ostrze noża z Bucov (ryc. 6.1) jest szersze od rękojeści i zakończone półokrągło. W przypadku innych zachowanych zabytków szerokość ostrza jest mniejsza lub równa szerokości rękojeści (Pleterski 1983, s. 180, Fig. 1). Znalezisko z cmentarzyska w Alczedar (ryc. 6.4) charakteryzuje się łukowato wygiętą głownią zachowaną na długości 5,4 cm, kształtem przypominającą ostrze półkoska. Dwa inne egzemplarze zdobione są ornamentem składającym się z nacięć w kształcie jodełki, analogicznym do znalezisk z Biskupina i Bonikowa (ryc. 3.2 i 3.3). Jednak w tych przypadkach zdobienie nie oddziela części pracującej od rękojeści. W trzech z przedstawionych na rycinie nożach (ryc. $6.5 ; 6.8 ; 6.11$ ) w wolutach zachowały się ogniwa po łańcuszku, który według badaczy miał pozwalać na zawieszenie ich przy pasie.

W 2017 roku ukazała się publikacja przedstawiająca odkrycie bogato wyposażonego, lecz zniszczonego pochówku ciałopalnego kobiety w okolicy Starej Pokrovky w obwodzie Charkowskim (Aksënov i Koloda 2017). Odnaleziono w nim zdobiony nóż wolutowy. Na tylnej części ostrza występował ornament zygzakowaty. Nóż znajdował się przy pasie wykonanym z ogniw łańcuszka (Aksënov i Koloda 2017, s. 53, ryc. 7) i prawdopodobnie umieszczony został w pochwie 

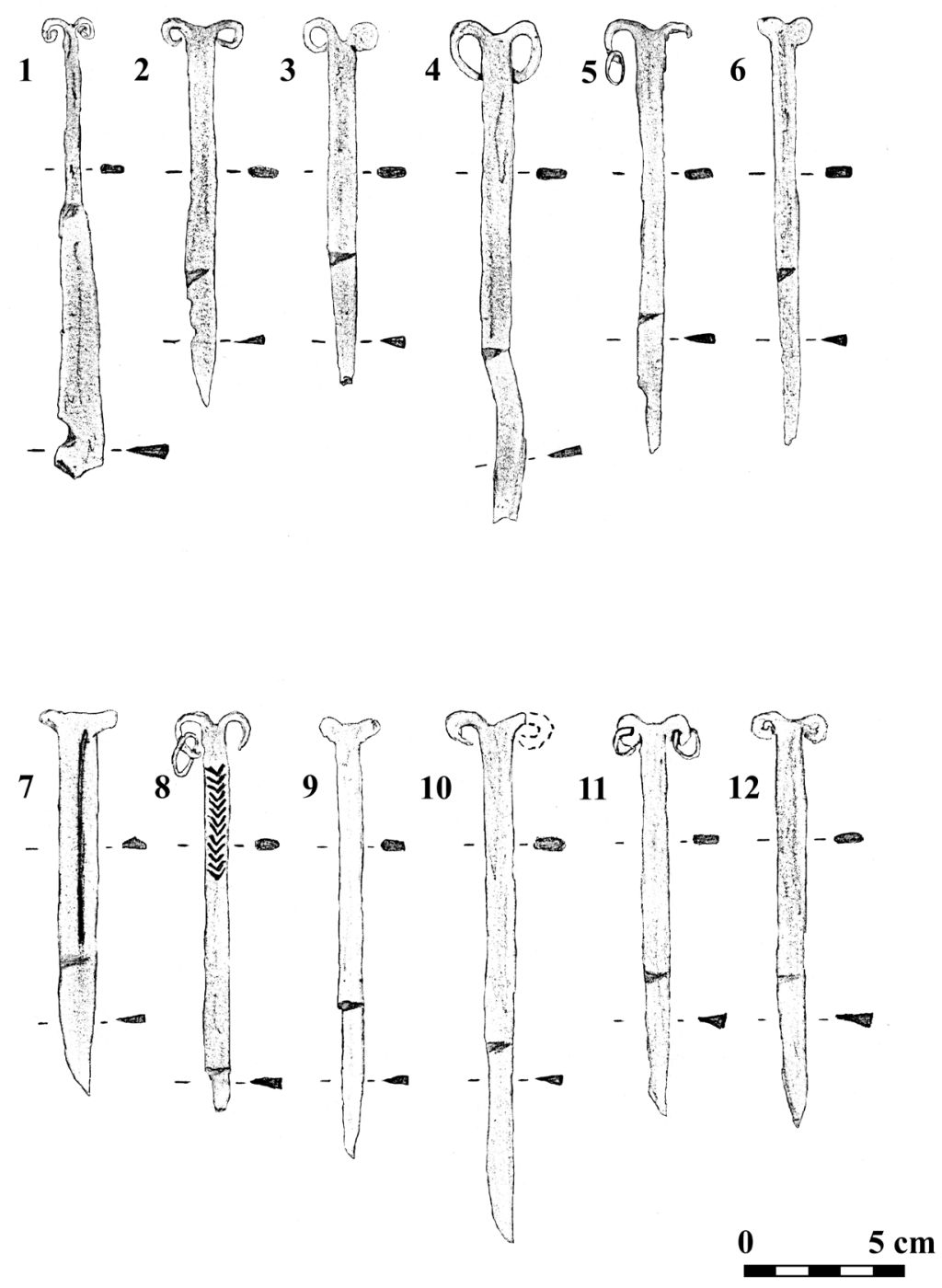

Ryc. 6. Noże wolutowe zespołu wschodniego: 1 - Bucov; 2 - Izvoarele; 3 - Lozna; 4 - Alcedar; 5 - Brănești; 6- Trebujeni; 7- Novotroickie; 8 - Plisniecko; 9 - Raškov, 10 - Revne ${ }^{I I}$ 11 - Ridkivci; 12 - Vypoziv. Rys. J.K. Pawlicki

wykonanej z drewna. Brak zawinięcia rozcięcia rękojeści uniemożliwiał zaczepienie łańcuszka bezpośrednio do noża, jak w przypadku innych zabytków. Problem stanowi przynależność kulturowa znaleziska, ponieważ oprócz pasa w wyposażeniu grobu znajdowały się przedmioty kojarzone z kulturą archeologiczną Saltovo-Mayaki, wydzielaną na terenach Stepu Pontyjskiego (Aksënov i Koloda 2017, s. 37-57). 
Noże ze Starej Pokrovky oraz z Novejpokrovki (Ajbabin 2013, s. 288) nie są wiązane ze Słowianami, w przeciwieństwie do większości zabytków tego zespołu. Wraz z zabytkami z Siemiluk oraz Šuklinka (Kovalevski 1998) mogą świadczyć o adaptacji tych przedmiotów w środowisku słowiańskim od koczowników.

Czas występowania noży wolutowych w tej grupie przypada na okres od schyłku VII do X wieku. Najstarsze znaleziska $\mathrm{z}$ tej grupy reprezentowane są przez egzemplarze z Novejpokrovki i Starej Pokrovky oraz terenów obecnej Mołdawii i Rumunii. Następny okres wiązany jest z rozpowszechnieniem się tych przedmiotów na terenie współczesnej Ukrainy. Znalezisko z Vipovziv (Močâ, Skorohod i Sitij 2014) jest obecnie jednym z najpewniej datowanych zabytków z terenów nad Dniestrem, a zarazem najmłodszym egzemplarzem. Odkryto go w kontekście osadniczym z końca IX i początku X wieku. Podobne datowanie odnosi się do okazów z miejscowości Revno w Obwodzie Czerniachowskim. Znaleziono tam dwa egzemplarze w kontekście osadniczym. Według badaczy na stanowisku znajdowało się centrum kultu przedchrześcijańskiego. Odkryto tam domniemane dwa sanktuaria pogańskie (Mys'ko 2012, s. 548). Obecnie to jedyne stanowisko o możliwym znaczeniu kultowym, gdzie odkryto noże wolutowe.

Zaskakujące są również rozmiary znalezisk zespołu wschodniego, których długość wahała się w granicach od 13,2 do 14,5 cm. W tym zbiorze wystąpił tylko jeden okaz o długości $17 \mathrm{~cm}$. Ich szerokość mieści się W zakresie od 0,8 do $1,5 \mathrm{~cm}$.

\section{Zespół pólnocny}

Strefa północna łącząca grupy VI i VII (Szymański 1988) położona jest na terenach górnego Dniepru, pomiędzy Niemnem a Dźwiną oraz obecną częścią północno-zachodniej Rosji. Omawiane zabytki występują najczęściej na stanowiskach znajdujących się na terenach nizinnych, zlokalizowanych w pobliżu dużych rzek. Zespół północny reprezentowany jest przez 11 egzemplarzy (ryc. 7), w tym aż osiem jest w pełni zachowanych. Jednym ze skupisk zabytków jest obszar nad górnym Dnieprem. Zagadkowa jest kwestia braku odkryć noży wolutowych na terenach pomiędzy obszarami tego zespołu a strefy wschodniej. Ta pustka rozciąga się na przestrzeni przeszło 350 kilometrów.

Egzemplarze tej grupy w większości pochodzą ze stanowisk osadniczych i tylko w jednym przypadku nóż stanowił wyposażenie grobu. Biorąc pod uwagę obecny stan badań, mamy do czynienia ze skromnym skupiskiem tych przedmiotów na omawianym terenie. Utrudnieniem analizy tego zespołu jest brak dokładnych rysunków noży wolutowych umożliwiających ustalenie obecności ornamentu. Podobnie jak w innych zespołach mamy do czynienia $\mathrm{z}$ obecnością kilku egzemplarzy noży na jednym stanowisku. Dotyczy to stanowiska w Revâčce, gdzie odkryto dwa 


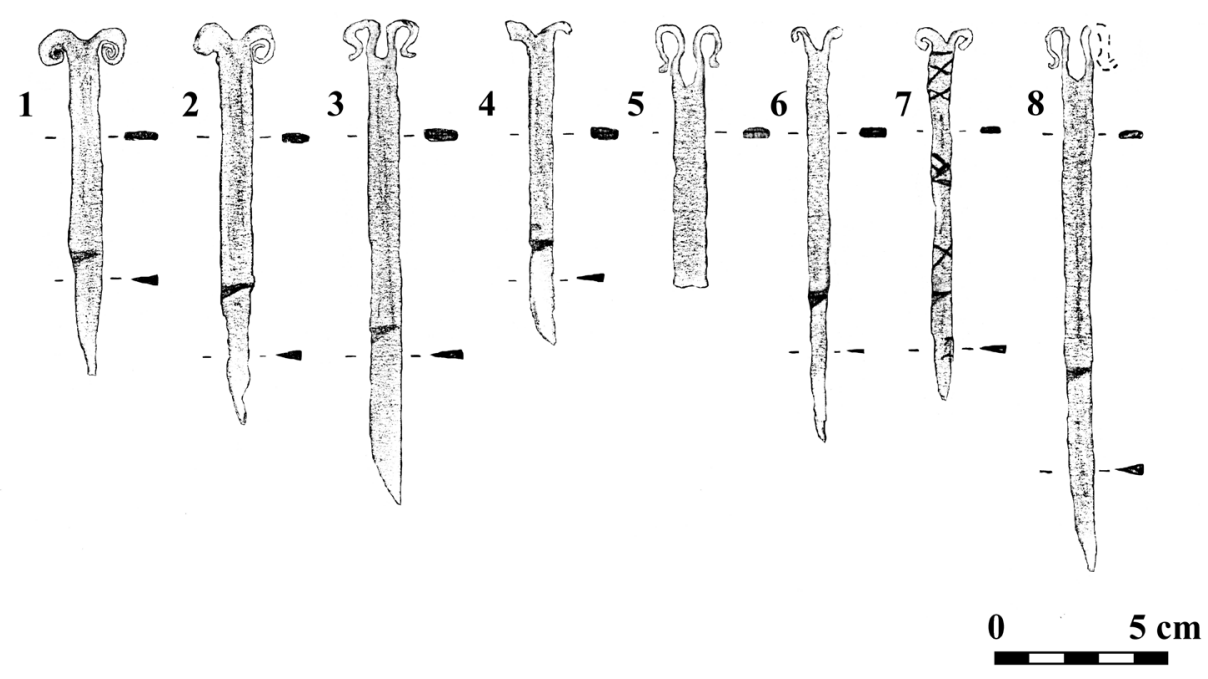

Ryc. 7. Zabytki strefy północnej: 1 - Horodyšče; 2 - Lukoml; 3 - Revâčka; 4 - Grigorovo; 5-7 - Gniezdovo; 8 - Jarcevo. Rys. J.K. Pawlicki

egzemplarze (tabele 55-56) i stanowiska w Gniezdovie z aż czterema egzemplarzami noży wolutowych (tabele 59-62), w tym dwoma w pełni zachowanymi.

Do niedawna badacze datowali stanowiska tego zespołu na podstawie materiału ceramicznego na okres od VII do IX wieku, uznając odkryte tam noże wolutowe za najstarsze. $\mathrm{Z}$ informacji zawartych w artykule Tamary Puškiny (2018) odnośnie do znalezisk z Gniezdova wynika, że przypisano im nową chronologię wpisującą się w horyzont środkowoeuropejski, tj. okres IX-X wieku.

Długość odkrytych noży zespołu północnego zawiera się w przedziale pomiędzy 9 a 16,6 cm, jednak większość zabytków nie przekracza $13 \mathrm{~cm}$. Szerokość rękojeści $\mathrm{w}$ tej grupie wpisuje się $\mathrm{w}$ przedział pomiędzy 0,6 a $1,5 \mathrm{~cm}$, najczęściej wynosi $0,8-0,9 \mathrm{~cm}$. Większość egzemplarzy jest krótsza i szersza niż noże wolutowe $\mathrm{w}$ innych zespołach czy grupach.

\section{Grupa nadwołżańska}

Grupa ta powiązana jest z Bułgarami Nadwołżańskimi. W kurhanach z grobami żeńskimi odkryto przedmioty zbliżone wyglądem do noży wolutowych, które według autora warte są zaprezentowania w tej pracy. Grupa ta składa się z ośmiu przedmiotów (ryc. 8), które przez badaczy tamtejszych stanowisk nie zostały zakwalifikowane jako noże wolutowe. Galina Matveeva (1997) oraz Anna Nikitina (2017, s. 69) w swoich pracach używają określeń szpila lub przedmiot 

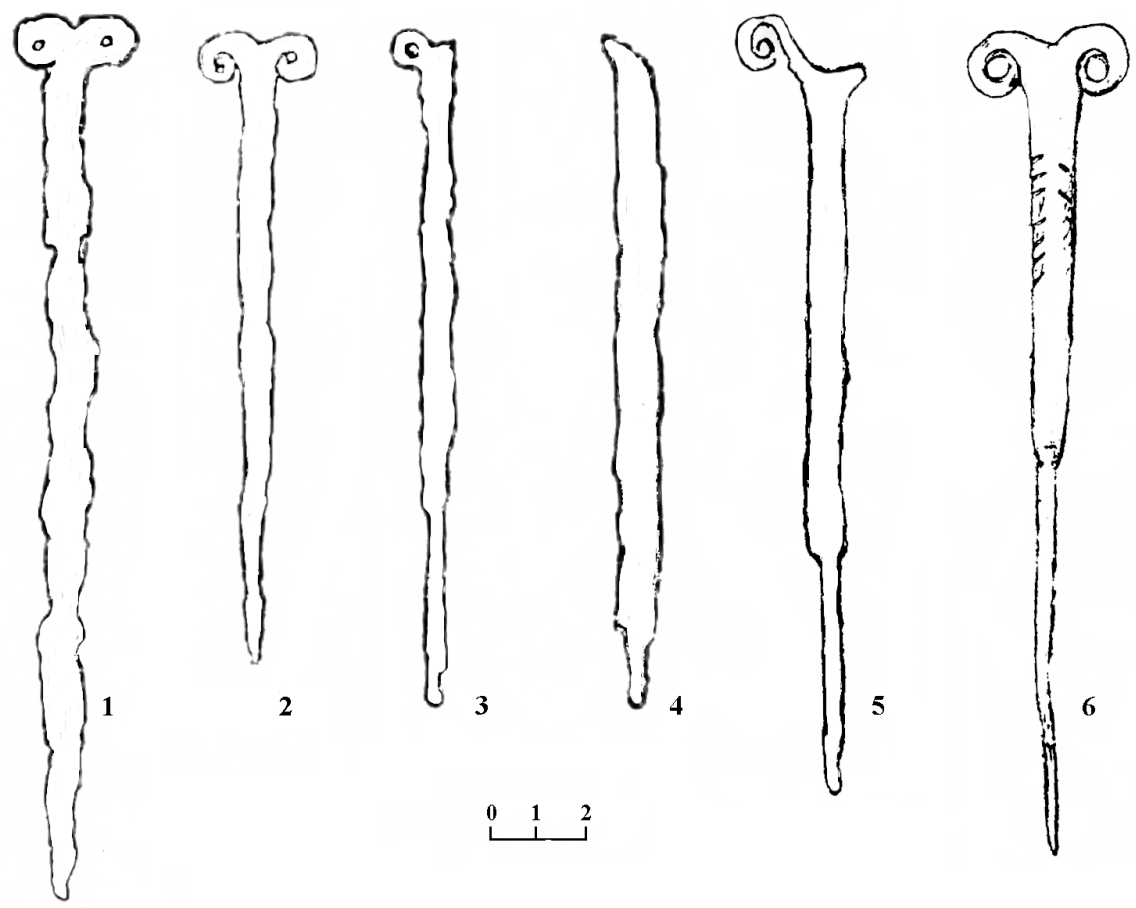

Rys. 8. Zabytki z regionu Zakola Samary: 1 - Roždestveno ${ }^{\mathrm{III}} ; 2$ - Novinki; 3 - Šelehmet'; 4-5 - Novinki; 6 - Oš-Pando-Nerv (za G. Matveeva 1997, rys. 120)

sztyletopodobny. Nazewnictwo tych wyrobów jako szpil wynika z umiejscowienia tych zabytków w okolicy klatki piersiowej w żeńskich grobach (Matveeva 1997, s. 62) oraz z cieńszych zakończeń dolnej części czterech egzemplarzy. Sześć zabytków tej grupy pozyskano podczas prac wykopaliskowych na cmentarzyskach kurhanowych. Natomiast dwa z nich stanowią znaleziska luźne, odkryte przypadkowo na terenach nadwołżańskich. Zostały one zebrane i skatalogowane przez Annę Nikitinę (2017).

Stanowiska w regionie Zakola Samary datowane są na VII wiek, będąc jednocześnie najstarszymi miejscami występowania przedmiotów z zakończeniem wolutowym. Pomimo różnic morfologicznych względem „typowych” noży wolutowych zostały one zaprezentowane w celu zwrócenia uwagi na podobną formę tych wyrobów. Mogą one stanowić pierwowzór opisywanych noży, które w wyniku przemieszczeń na zachód zatraciły swoją pierwotną formę i funkcję. Jednym z przykładów takiej „wędrówki” noży wolutowych ze wschodu może być znalezisko z Novejpokrovki (Ajbabin 2013, s. 288, 309, ryc. 4), wiązane z koczownikami. Nóż na tym stanowisku został złożony w żeńskim grobie w okolicy miednicy zmarłej. Jego datowanie określa się na przełom VII i VIII wieku, czyli około pół 
wieku wcześniej niż noże zakończone wolutą na stanowiskach o charakterze słowiańskim.

\subsection{Grupa azjatycka}

Grupa azjatycka, z terenu Kotliny Minusińskiej na Syberii, charakteryzuje się występowaniem przedstawień noży wolutowych jako detali na rzeźbach kamiennych. Rzeźby te wiązane są z grupą koczowników z ludu Połowców (Mys’ko i Pivovarov 2010, s. 4; Savinov 1984, s. 115-122). Jest to kolejny przykład obecności przedmiotów o charakterze podobnym do noży wolutowych poza kulturą etniczną Słowian. Reprezentowana jest przez trzy detale (Savinov 1984, s. 116, ryc. 1.5-7), które zostały przerysowane z tak zwanych bab połowieckich (Mys'ko i Pivovarov 2010, s. 5, ryc. 4). Przedstawienia z rzeźb zostały uwzględnione w tekście, ponieważ spełniają wizualne kryteria noży wolutowych. Wśród innych rytów na rzeźbach przedstawiających strój i jego elementy widnieją też inne kategorie zabytków zakończonych wolutami - między innymi widelce.

\section{FUNKCJA NOŻY WOLUTOWYCH}

Wraz z odkryciem każdego nowego noża wolutowego pojawia się więcej pytań niż odpowiedzi. Autorzy tekstów, powołując się na obecne w literaturze interpretacje, nie próbują wyjaśnić ich funkcji. Sytuacji nie ułatwia niemal zupełny brak analiz specjalistycznych tego typu przedmiotów, choć trzeba zaznaczyć, że wyniki takich badań mogą być jedynie przesłanką co do interpretacji ich faktycznego przeznaczenia. Literatura dotycząca tego zagadnienia zawiera cztery główne teorie odnośnie do zastosowania noży wolutowych w przeszłości, na które powołują się wszyscy autorzy zajmujący się, mniej lub bardziej pobieżnie, problematyką tych zagadkowych przedmiotów. Pomimo charakterystycznej formy noży wolutowych ich funkcja nie została dotychczas dokładnie przeanalizowana. Nie przedstawiono też wiarygodnego dowodu wskazującego bezpośrednio na jedną z teorii.

Rozpatrując problem zastosowania noży wolutowych, należy się też zastanowić, czy na wszystkich obszarach ich występowania używane były one w sposób identyczny. Wyżej wspomniano już o odmienności typologicznej okazów grupy nadwołżańskiej. Jak wykazano, wśród wyróżnionych grup widoczne jest też znaczne zróżnicowanie metryczne. W niektórych przypadkach możemy jedynie powiedzieć o pewnego rodzaju standaryzacji funkcjonującej wyłącznie regionalnie i niemającej odzwierciedlenia w analizie całościowej zespołu. Cechą łączącą wszystkie grupy była natomiast szerokość rękojeści zabytków, której średnia wartość skupiała się w przedziale od 1 do $1,3 \mathrm{~cm}$. Przedstawione na wykresie poniżej dane (ryc. 13) nie oddają cech metrycznych w poszczególnych regionach, a jedynie wynik 


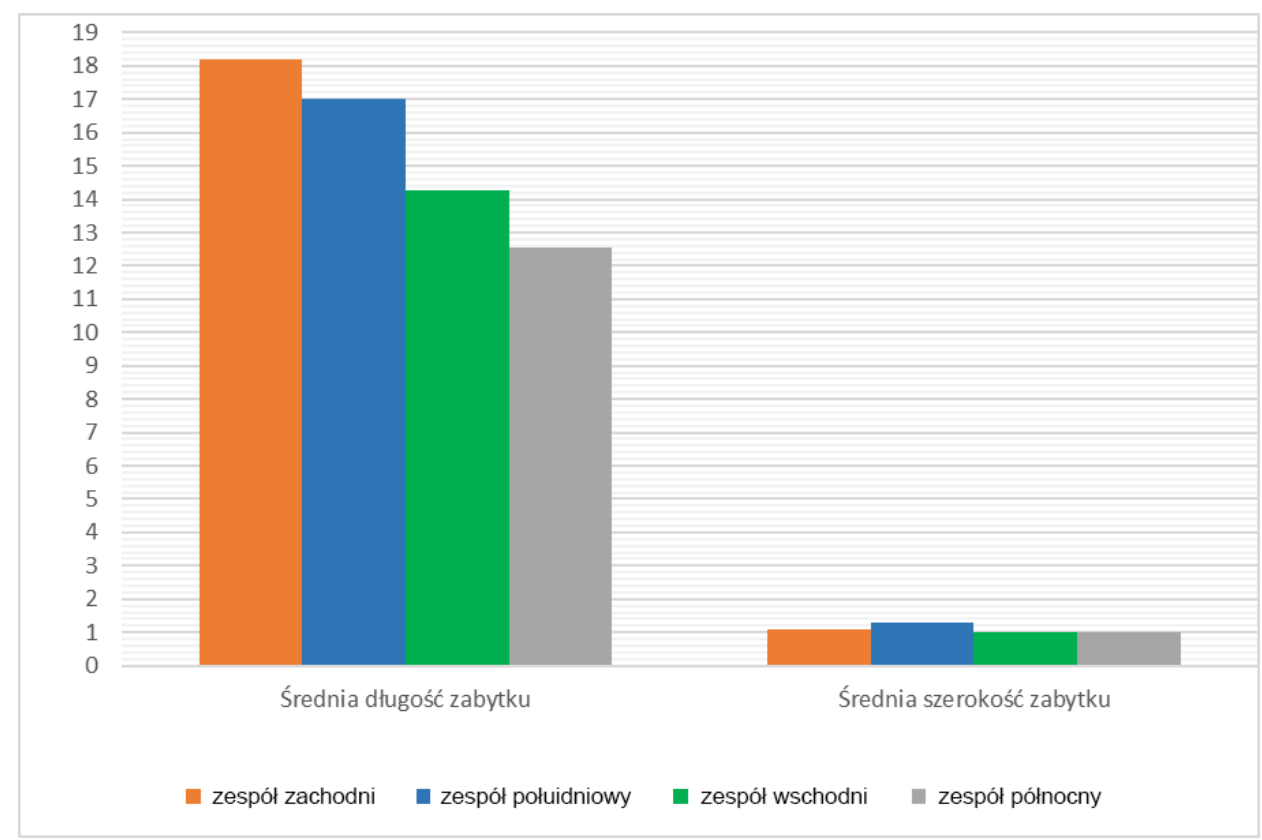

Ryc. 9. Wykres przedstawiający średnie długości i szerokości noży wolutowych w wyznaczonych zespołach, wartości podane w centymetrach. Oprac. J.K. Pawlicki

średniej wymiarów zachowanych zabytków możliwych do analizy. Obecność takiej samej formy zabytku $\mathrm{z}$ różnicami w rozmiarach, ale istniejącej wśród wszystkich grup Słowian, również stanowiła argument tworzący pewnego rodzaju powiązanie między tymi grupami, a być może także przemawia za podobną rolą tych przedmiotów w różnych kręgach kulturowych.

\section{FUNKCJA KULTOWA}

Funkcja kultowa noży wolutowych była brana pod uwagę od samego początku badań nad tym tematem (Szymański 1964, s. 221-228). Argumentem przemawiającym na korzyść tej interpretacji była znikoma liczba przedmiotów tego rodzaju na całym obszarze zajmowanym przez kultury słowiańskie. Po 55 latach od czasu opublikowania pierwszych artykułów zbiorczych na temat noży wolutowych baza źródłowa wzrosła z 46 zabytków wymienionych w pracy Wojciecha Szymańskiego do 72 egzemplarzy. Tak skromna liczba znalezisk może wskazywać na wyjątkowe znaczenie tego przedmiotu w przeszłości. Autorzy publikacji zauważają istotną rolę w obecności tych zabytków na cmentarzyskach. Początkowo uważano, że noże wolutowe w grobach stanowiły wyznacznik pozycji społecznej (Gardawski 1951, 
s. 127-138), jednak pochówki te wcale nie charakteryzowały się bogatym wyposażeniem (ryc. 5). Kolejna interpretacja zakładała, że noże te stanowiły wyznacznik grobów kapłanów kultu pogańskiego. Tej teorii przeczy częsta obecność tego rodzaju zabytków w grobach dziecięcych (tabele 25, 27). Nóż wolutowy z Góry Birów łączony jest ze strefą sepulkralną poprzez znalezienie go w pobliżu pochówków kurhanowych (Muzolf 1994, s. 259-270), jednak sam autor publikacji nie jest pewny kontekstu znaleziska. Nóż z Gledzianówka został pominięty w rozważaniach nad zabytkami z cmentarzysk, ponieważ jego związek z wyposażeniem grobowym został odrzucony.

Wojciech Szymański w swojej pracy z 1988 roku zwraca uwagę na grób w Zwolfaxing, gdzie w grobie dziecięcym znajdował się nóż wolutowy oraz szczątki kostne drobiu złożone w naczyniu (Szymański 1988, s. 156). Można przywołać tu analogię do pewnego zwyczaju obecnego w folklorze Słowian strefy południowej, którzy mieli ogromny wpływ na praktyki związane z rolnictwem wśród osiadłych koczowników. Dane etnograficzne z tego obszaru mówią o obrzędach $\mathrm{z}$ zastosowaniem drobiu w zwyczajach związanych z pracą na roli. Pierwszy z nich polegał na zabijaniu kury/koguta nad garnkiem, w którym znajdowało się zboże do zasiewu (Wakarelski 1965, s. 308). Kolejny przykład dawnej tradycji związanej z zakończeniem działań rolniczych - żniw i młócenia zboża - zachowany jest jedynie w zawołaniach określających czynność „zabicia koguta” (Wakarelski 1965, s. 308). Praktyki te, choć znane już z relacji nowożytnych, odnoszone są do czasów wczesnego średniowiecza i panujących wówczas obyczajów pogańskich. W niektórych obiektach, w których odkryto noże wolutowe, jak np. w Żukowicach, również zachowały się szczątki kostne, między innymi kości drobiu (Parczewski 1989). Raczej nie można wiązać ich ze zwyczajem opisywanym wyżej, szczególnie biorąc pod uwagę fakt, że na pozostałych stanowiskach zabytki znajdowały się w warstwach kulturowych, jamach, stokach wału i w obiektach mieszkalnych.

Stanowiska Revne (Mys'ko 2012, s. 548) na Ukrainie zaliczają się do wydzielonych w literaturze miejsc kultu pogańskiego (Mihajlina 2007, s. 200). Tego typu sugestie pojawiły się również odnośnie do przestrzeni, na której wybudowano grodzisko w Bonikowie (Kara 2009, s. 107, ryc. 21; Kobusiewicz 2008). Jak przedstawiono powyżej - noże wolutowe nie są odnajdywane na kluczowych miejscach kultu pogańskiego z tamtego okresu. O roli kultowej miałby świadczyć nagły zanik tych przedmiotów w materiałach późniejszych, wiązanych już z okresem chrystianizacji. Według badaczy, w wyniku przyjęcia chrześcijaństwa kult pogański został przerwany, co wiązało się z zaprzestaniem produkcji noży wolutowych (Pleterski 1983, s. 387, 393). Argumentacja ta nie do końca przekonuje. Oficjalne przyjęcie religii chrystusowej nie wyeliminowało tzw. przeżytków pogańskich praktykowanych w kolejnych stuleciach (Moździoch 2011, s. 150). Zanik noży wolutowych może mieć natomiast związek ze znacznymi zmianami w kulturze materialnej Europy $\mathrm{w}$ dobie kształtowania się państw. 

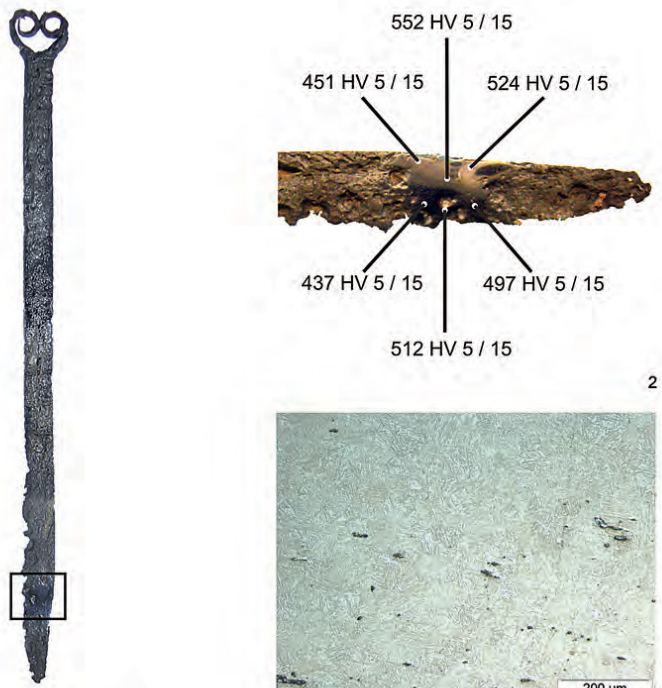

1
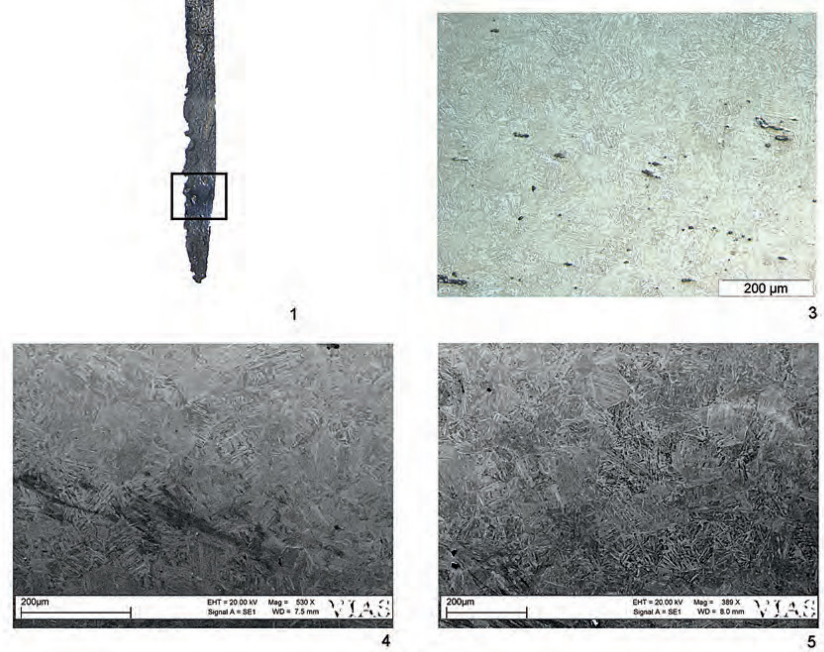

Ryc. 10. Wyniki badania metalograficznego z Thanau am Kamp (za E. Nowotny 201, taf. 81)

\section{Skalpel, nóż chirurgiczny}

Teza ta została zaproponowana przez Andrzeja Pleterskiego (1983, s. 387) na podstawie analogii do noży chirurgicznych. Następnie badania nad tym tematem kontynuował Wojciech Szymański (1988), podając analogie do wyposażenia grobu w Koszthely oraz przedmiotów z innego grobu zakwalifikowanych do funkcji chirurgiczno-kapłańskich (Szymański 1988, s. 156). Dodatkowo przypuszczenie o funkcji narzędzi chirurgicznych uwiarygadnia sterylność zapewniona przez wykonanie ich tylko z żelaza. Umożliwia to proces dezynfekcji polegający na wygotowaniu ich we wrzątku. Sterylność nie byłaby możliwa do zachowania, gdyby przedmioty te posiadały okładzinę $\mathrm{z}$ surowców organicznych. W tym przypadku trzeba brać pod uwagę poziom wiedzy i umiejętności potrzebnych przy najprostszych operacjach. Powstaje pytanie, czy ludzie posługujący się tego typu przedmiotem ją posiadali? Dziś to zagadnienie jest niemożliwe do zweryfikowania. 
Podobnie jak w przypadku funkcji kultowej, trzeba zwrócić uwagę na groby młodych osób. Nie jesteśmy w stanie odpowiedzieć, czy posiadali kwalifikacje do wykonania tych czynności. Problemem w weryfikacji jest też obrządek pogrzebowy, tj. na wielu obszarach występowania noży wolutowych - ciałopalenie lub pochówki niewykrywalne metodami archeologicznymi. Uniemożliwia to przyjrzenie się materiałowi kostnemu i śladom po operacjach, podobnie jak rozkład ciała ludzkiego, oczywisty ze względu na klimat. Destrukcja ciała nie pozwala na przebadanie tkanek miękkich czy blizn skórnych powstałych po zabiegach chirurgicznych.

Za możliwością wykorzystania noży wolutowych jako narzędzi chirurgicznych przemawiają analizy metalograficzne zabytku z cmentarzyska z Thunau am Kamp (ryc. 10). Badania i interpretacje przeprowadzone przez Ericha Naua i Mathiasa Mehofera (Nowotny 2018, s. 366) wskazują, że ten egzemplarz został wykonany w sposób dokładniejszy i z lepszego surowca niż pozostałe noże użytkowe z tamtego regionu. Badacze twierdzą, że spełnia on normy wykorzystywane przy produkcji narzędzi chirurgicznych, wskazując analogię do tak zwanych noży chirurgicznych z Czech (Hošek i in. 2007, s. 932-937) datowanych na X wiek. Wyniki metalograficzne tych przedmiotów zbliżone są do wyników badań zabytku z Thunau am Kamp. Skalpele z późniejszego okresu różnią się od noży wolutowych obecnością okrągłej w przekroju rękojeści oraz brakiem wolut, jednak kształt ostrza i rozmiar jest niezmienny (Hošek i in. 2007, s. 933, ryc. 1). Kolejnym aspektem łączącym te przedmioty z nożami wolutowymi jest fakt, że noże z cmentarzysk w Klecanach oraz Bášt’ również znajdowały się w grobach kobiecych. Niestety, brak badań metalograficznych na pozostałych nożach wolutowych nie pozwala na jednoznaczne stwierdzenie, czy one wszystkie odznaczały się tak wysokim standardem wykonania.

\section{Nóż szewski}

Teoria ta zaproponowana została przez Mihaila Kučerę, badacza stanowiska Plisniecko na terenie obecnej Ukrainy (Kučera 1962). Autor uważał, że nóż wolutowy znaleziony w reliktach budynku spełniał rolę noża szewskiego. Porównując narzędzia szewskie z ich charakterystyczną krótką, ale szeroką głownią (Turanu 1983, ryc. 22), nie można stwierdzić, że przypominały one noże wolutowe. Argumentem świadczącym na niekorzyść tej tezy jest również fakt, że zabytki te nie są znajdywane jedynie w budynkach. Noże będące tematem tej pracy występują między innymi w jamach gospodarczych, grobach, czy też w warstwach kulturowych, niepowiązanych z rzemiosłem. Kolejnym argumentem przeciwko tej interpretacji jest brak widocznych śladów spracowania powierzchni oraz opisane w akapicie powyżej właściwości świadczące o staranności i jakości wykonania noży wolutowych. Podobnie jak obecność noży z wolutowym zakończeniem 
rękojeści tylko w strefie słowiańskiej i ich brakiem w zachodniej Europie, gdzie również funkcjonowali szewcy.

\section{Krój płużny}

Interpretacja noża wolutowego jako kroju płużnego została zaproponowana przez Aleksandra Gardawskiego (1951) utożsamiającego zabytki z Gledzianówka z przedmiotami z okresu wpływów rzymskich. Zwolennicy tej tezy powołują się na analogię do kształtu miniatury kroju płużnego (Hemple 1905, s. 19, taf. 14o) znajdującego się na naszyjniku z Şimleul-Silvaniei. Miniatura znajduje się w parze z radlicą i przypomina krój płużny. Górna część przedmiotu miniaturowego zakończona jest wolutą; nie wiadomo jednak, czy miałaby ona spełniać funkcję jedynie ozdobną czy zakończenie w kształcie spirali zapewniałoby lepsze zamocowanie kroju w grządzieli. Analogią do miniatury jest znalezisko z Tinje nad Loko przy Žusmu (Ciglenečki 2000). Autor monografii interpretuje ten przedmiot jako krój płużny lub nóż winiarski, zaliczając go do późnego okresu rzymskiego, tj. IV-V wieku. Przedmiot ten w przeciwieństwie do noży wolutowych charakteryzuje się znacznie większą szerokością ostrza niż rękojeści (Ciglenečki 2000, s. 198, t. 2.4). Gdyby zabytki z wczesnego średniowiecza miały stanowić miniaturki krojów płużnych, należałoby wiązać je z kultem agralnym. Mogłyby być używane podczas obrzędów związanych z pierwszym zasiewem lub przygotowywaniem pól. Brak śladów zniszczeń krawędzi ostrza świadczy jednak na niekorzyść tej teorii.

\section{PODSUMOWANIE}

Ponowna analiza tych szczególnych narzędzi pozwoliła odnieść się do istniejących koncepcji na ich temat, przyniosła jednak także szereg nowych niejasności. Po przeprowadzeniu analiz metrycznych uwidoczniło się pytanie: czy długości przedmiotów w jakikolwiek sposób miały wpływ na ich funkcję? Długość zabytków różniła się bowiem wewnątrz poszczególnych zespołów i nie była jednakowa nawet na tych samych stanowiskach. Prawdopodobnie w przypadku noży wolutowych ważniejsza od długości była ich szerokość, stanowiąca ustandaryzowaną miarę we wszystkich regionach ich występowania.

Studia przyniosły także nowe ustalenia dotyczące genezy noży wolutowych. Szczególnie intrygująca jest obecność tak zwanych przedmiotów sztyletopodobnych na terenach położonych nad Wołgą, w regionie Samary. Wczesne datowanie zabytków z tamtego regionu zdaje się świadczyć o powstaniu idei i formy noży wolutowych właśnie na terenie nadwołżańskim. Mogłyby być one sprowadzone do świata Słowian przez wędrujących ze wschodu koczowników. Wyjaśnienie tego problemu przyniesie być może dokładna analiza chronologii zabytków z tego 
obszaru i terenów Słowiańszczyzny oraz próba odtworzenia szlaku rozpowszechnienia się noży wolutowych w zespołach koczowniczych i słowiańskich.

Następnym etapem badań powinna być próba przypisania nożom wolutowym z terenów Polski interpretacji kulturowej wzorowanej na przykładach analiz zabytków z Mołdawii czy terenów pomiędzy Prutem a Dniestrem. Ważnym elementem prac nad tematem powinno być przyjrzenie się motywom zdobniczym oraz ich powtarzalności na zabytkach w różnych zespołach.

Problem określenia rzeczywistego przeznaczenia tych przedmiotów, który był głównym celem niniejszego opracowania, nie jest na obecną chwilę możliwy do rozstrzygnięcia. Po przeprowadzeniu analizy nad zasadnością teorii zastosowań noży wolutowych wyraźnie zarysowują się dwie teorie: funkcja kultowa i funkcja narzędzia chirurgicznego. Pierwsza z koncepcji jest trudna do podważenia, ale również do potwierdzenia. Przypisanie noży wolutowych do sfery sacrum niejako ,szufladkuje" je jako przedmioty o znaczeniu trudnym do określenia, czego efektem jest brak prób dążących do określenia sposobu faktycznego ich użytkowania. Trzeba też zaznaczyć, że teoria zaproponowana przez Andrzeja Pleterskiego (1993) o wykorzystywaniu noży zwieńczonych wolutami jako narzędzi medycznych nie wyklucza odprawiania pewnego rodzaju rytuałów mogących towarzyszyć operacji - mielibyśmy wtedy do czynienia z połączeniem obu dominujących funkcji.

$\mathrm{Na}$ podstawie analiz występowania noży w grobach (Daim 1987, s. 268; Matveeva 1997, s. 62; Ajababin 2013, s. 288) czy na kamiennych rzeźbach Połowców w interpretacjach faktycznego przeznaczenia noży wolutowych bardzo mocno uwidacznia się pierwiastek żeński. Nóż był wyeksponowany przy pasie obok innych elementów mogących świadczących o roli czy pozycji społecznej kobiety. Taki sposób ekspozycji widzimy na rzeźbach Połowców (Mys’ko i Pivovarov 2010, s. 5, ryc. 4) oraz możemy zrekonstruować go za pomocą znaleziska pasa ze Starej Pokrovki (Aksënov i Koloda 2017, s. 53, ryc. 7). W rozważaniach dotyczących roli kultowej dość często pojawia się wątek płodności. Dodając do tego interpretację związaną z nożami chirurgicznymi, nie można wykluczyć, że taki przyrząd stanowił wyposażenie ,zielarki” lub „akuszerki”. Na podstawie przedstawień sztuki antycznej, między innymi płaskorzeźby przedstawiającej poród z Ostii, oraz sztuki średniowiecznej zaobserwować można prawidłowość, iż kobietą rodzącą i niemowlęciem zajmują się postacie kobiece.

Zabytki takie jak noże wolutowe są dowodem na to, jak niewiele wiemy o obrzędowości Słowian oraz o wiedzy, jaką posiadali. Uwidaczniają też problem braku specjalistycznych badań nad tą kategorią przedmiotów, czego dobitnym przykładem są obiecujące rezultaty takich analiz, przeprowadzone, niestety, tylko dla jednego (!) zabytku. Przeprowadzenie badań metalograficznych na kilku odkrytych już wcześniej nożach pozwoliłoby potwierdzić lub obalić tezę o staranności wykonania i jakości surowca użytego do produkcji noży wolutowych. Wyniki te ułatwiłaby interpretację funkcji tych zagadkowych znalezisk. 
Noże wolutowe - o funkcji i pochodzeniu zagadkowych przedmiotów...

\begin{tabular}{|c|c|c|c|c|c|c|}
\hline 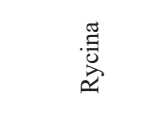 & $\begin{array}{l}\vec{m} \\
\dot{\vec{\phi}} \\
\dot{\propto}\end{array}$ & 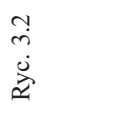 & 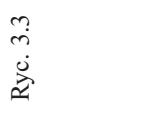 & 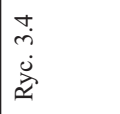 & 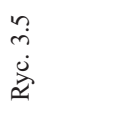 & \\
\hline 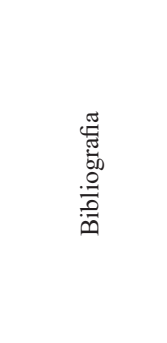 & 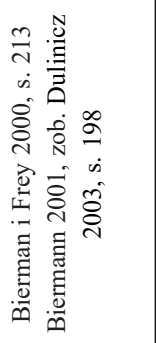 & 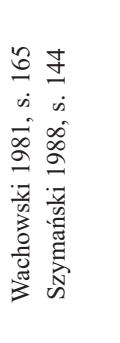 & 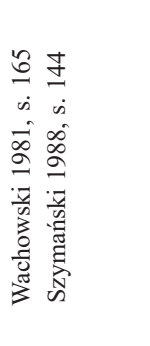 & 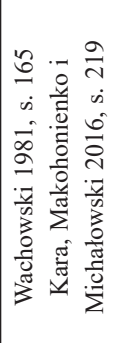 & 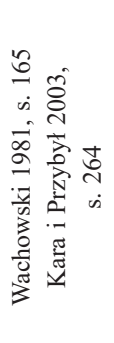 & 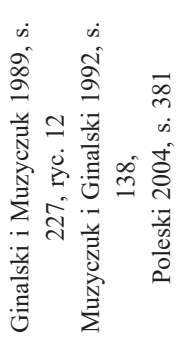 \\
\hline $\begin{array}{l}\sqrt{60} \\
\mathbb{5} \\
5 \\
5\end{array}$ & & 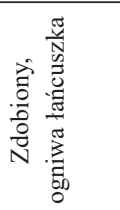 & & 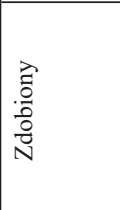 & & 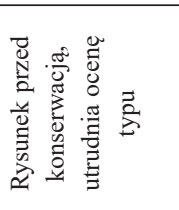 \\
\hline$\stackrel{\curvearrowright}{\Leftrightarrow}$ & $\underbrace{N}_{F}$ & $\overbrace{\beta}^{N}$ & $\overbrace{\beta}^{N}$ & $\stackrel{n}{n}$ & $\overbrace{\beta}^{N}$ & \\
\hline 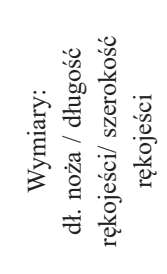 & 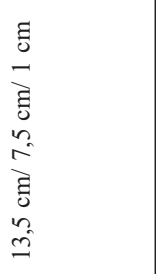 & 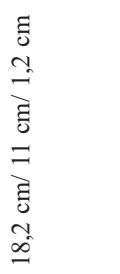 & 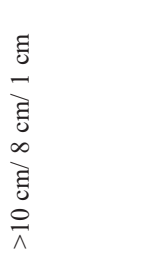 & 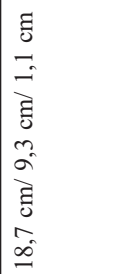 & 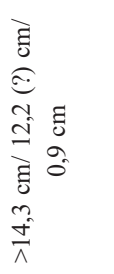 & 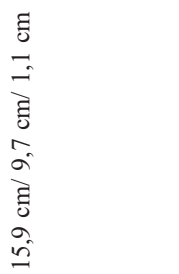 \\
\hline 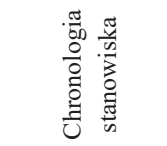 & $\begin{array}{l}\stackrel{3}{x} \\
\\
\ddot{u}\end{array}$ & $\begin{array}{l}\stackrel{3}{x} \\
\stackrel{x}{\dot{y}} \\
\dot{\beta}\end{array}$ & $\begin{array}{l}\stackrel{3}{x} \\
\stackrel{x}{j}\end{array}$ & $\begin{array}{l}\dot{3} \\
\stackrel{x}{x} \\
\ddot{u}\end{array}$ & $\dot{3}$ & $\begin{array}{l}3 \\
\text { 离 } \\
3\end{array}$ \\
\hline 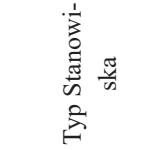 & $\begin{array}{l}\frac{8}{0} \\
\frac{1}{1} \\
0 \\
0 \\
0\end{array}$ & 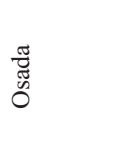 & $\begin{array}{l}\text { 逽 } \\
0 \\
0\end{array}$ & 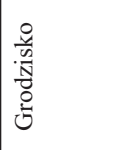 & $\begin{array}{l}\underset{\overparen{\varpi}}{\mathscr{W}} \\
0 \\
0\end{array}$ & $\begin{array}{l}\frac{8}{0} \\
\frac{0}{0} \\
\frac{\pi}{0} \\
0 \\
0\end{array}$ \\
\hline 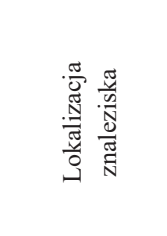 & 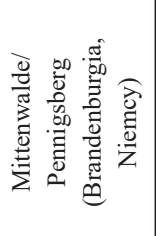 & 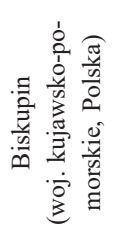 & 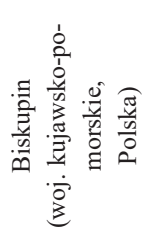 & 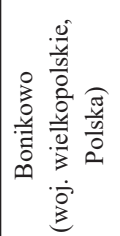 & 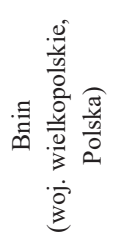 & 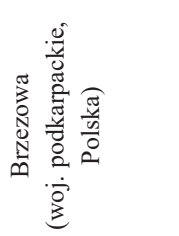 \\
\hline Grupa & \multicolumn{6}{|c|}{ Zespół zachodni } \\
\hline בి & - & $\sim$ & $m$ & $\forall$ & in & 6 \\
\hline
\end{tabular}




\begin{tabular}{|c|c|c|c|c|c|c|c|c|}
\hline $\begin{array}{l}\dot{0} \\
\dot{r} \\
\dot{0}\end{array}$ & $\begin{array}{l}\overrightarrow{\dot{m}} \\
\dot{\vec{b}}\end{array}$ & $\begin{array}{l}\infty \\
\dot{m} \\
\dot{0} \\
\stackrel{2}{2}\end{array}$ & $\begin{array}{l}\stackrel{\partial}{\vec{r}} \\
\dot{0} \\
\dot{\partial}\end{array}$ & 1 & $\begin{array}{l}\stackrel{\rho}{\leftrightarrow} \\
\dot{m} \\
\dot{0}\end{array}$ & $\begin{array}{l}\exists \\
\vec{m} \\
\dot{0}\end{array}$ & $\begin{array}{l}\mathcal{H} \\
\dot{m} \\
\dot{0}\end{array}$ & $\begin{array}{l}\stackrel{m}{m} \\
\dot{m} \\
\dot{0}\end{array}$ \\
\hline 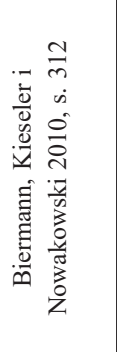 & 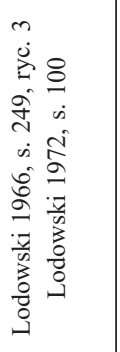 & 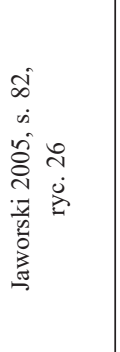 & 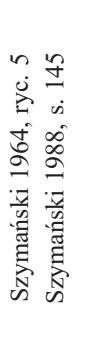 & 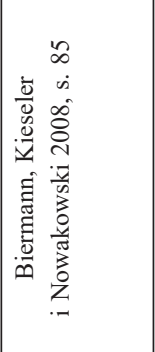 & 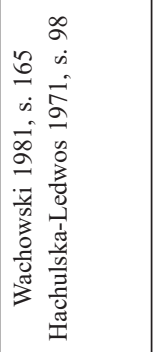 & 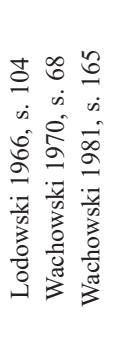 & 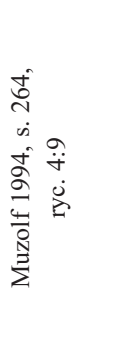 & 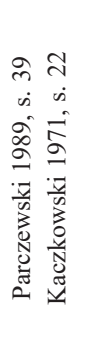 \\
\hline 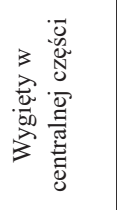 & $\begin{array}{l}\text { 总 } \\
\text { : } \\
\stackrel{0}{0}\end{array}$ & 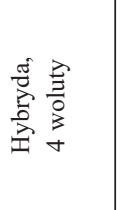 & 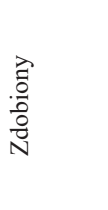 & 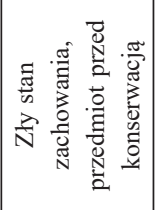 & & 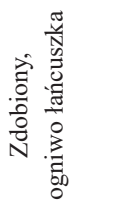 & & \\
\hline$\vec{s}$ & $\stackrel{2}{\beta}$ & & $\vec{s}$ & 点 & $\stackrel{N}{\beta}$ & $\stackrel{N}{\beta}$ & $\vec{s}$ & $\vec{s}$ \\
\hline 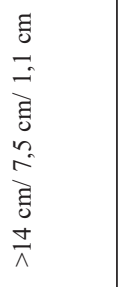 & 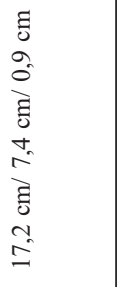 & $\begin{array}{l}\text { घี } \\
\infty \\
0 \\
0 \\
\text { है } \\
2 \\
2 \\
\text { हे } \\
\infty \\
0\end{array}$ & 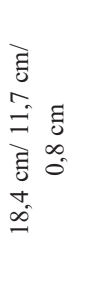 & 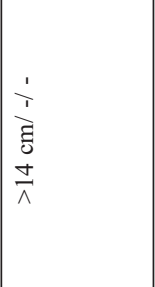 & 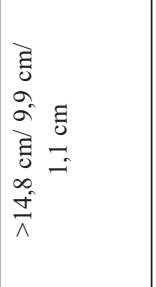 & 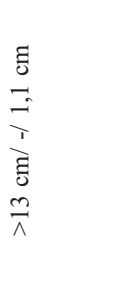 & 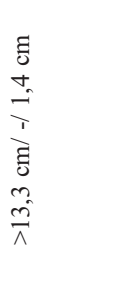 & 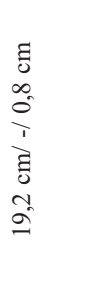 \\
\hline 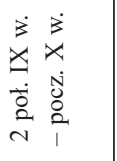 & $\begin{array}{l}\stackrel{3}{3} \\
\dot{y} \\
\dot{J}\end{array}$ & $\begin{array}{l}\stackrel{3}{x} \\
\ddot{x} \\
\ddot{u}\end{array}$ & 1 & $\begin{array}{l}\dot{3} \\
\dot{x} \\
\ddot{x}\end{array}$ & $\begin{array}{l}\stackrel{3}{3} \\
\dot{⿱ 亠 幺} \\
\end{array}$ & $\begin{array}{l}\stackrel{3}{3} \\
\dot{x} \\
\dot{J}\end{array}$ & 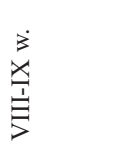 & 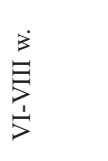 \\
\hline $\begin{array}{l}\frac{8}{.0} \\
\frac{n}{0} \\
0 \\
0\end{array}$ & $\begin{array}{l}\underset{\widetilde{Z}}{\mathbb{Z}} \\
0 \\
0\end{array}$ & $\begin{array}{l}0 \\
\frac{8}{0} \\
\frac{5}{N} \\
0 \\
0 \\
0\end{array}$ & 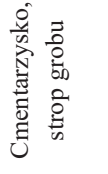 & $\begin{array}{l}\frac{8}{0} \\
\frac{0}{\pi} \\
\frac{\pi}{0} \\
\dot{0}\end{array}$ & $\begin{array}{l}\text { 苋 } \\
\text { OD }\end{array}$ & $\begin{array}{l}\text { 苋 } \\
\text { Oֶ. }\end{array}$ & $\begin{array}{l}\frac{8}{.} \\
\frac{1}{N} \\
0 \\
0 \\
0\end{array}$ & $\begin{array}{l}\frac{\pi}{\mathscr{Z}} \\
0 \\
0\end{array}$ \\
\hline 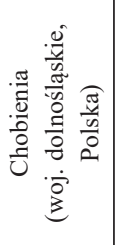 & 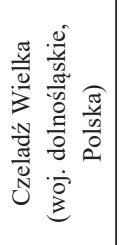 & 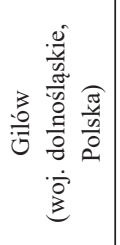 & 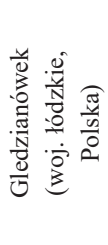 & 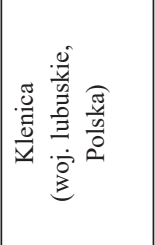 & 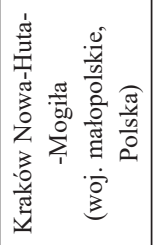 & 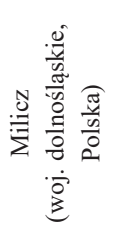 & 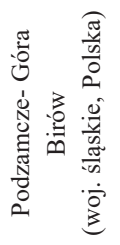 & 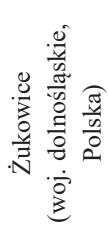 \\
\hline$r$ & $\infty$ & $a$ & 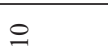 & $=$ & $\simeq$ & $\cong$ & \pm & $\cong$ \\
\hline
\end{tabular}


Noże wolutowe - o funkcji i pochodzeniu zagadkowych przedmiotów...

\begin{tabular}{|c|c|c|c|c|c|c|c|c|}
\hline 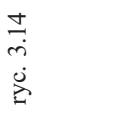 & $\begin{array}{l}\underset{+}{+} \\
\dot{0}\end{array}$ & 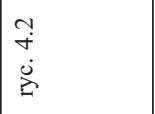 & 1 & $\begin{array}{l}\stackrel{m}{+} \\
\dot{0} \\
\stackrel{2}{*}\end{array}$ & $\begin{array}{l}\stackrel{+}{+} \\
\stackrel{0}{\vec{b}}\end{array}$ & 1 & $\begin{array}{l}\stackrel{n}{+} \\
\dot{0} \\
\stackrel{2}{*}\end{array}$ & $\begin{array}{l}\stackrel{0}{+} \\
\stackrel{+}{0} \\
\dot{0}\end{array}$ \\
\hline 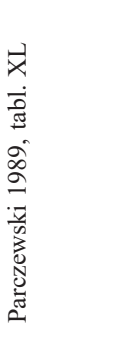 & 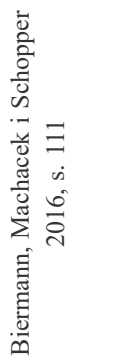 & 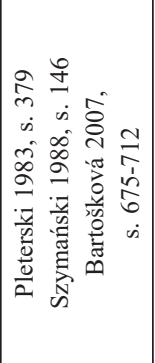 & 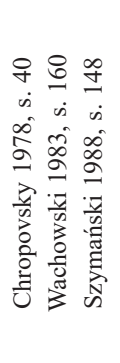 & 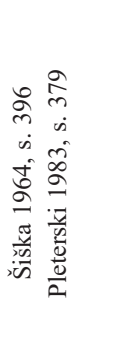 & 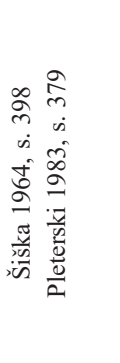 & 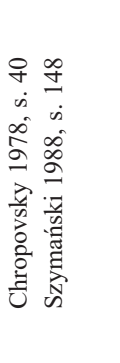 & 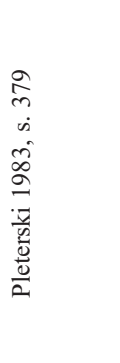 & 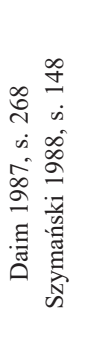 \\
\hline \multirow[t]{2}{*}{ 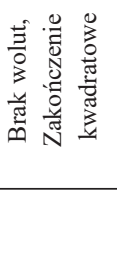 } & 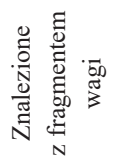 & & & & & & & \\
\hline & $\vec{s}$ & 第 & & $\vec{s}$ & 第 & & $\vec{s}$ & $\vec{s}$ \\
\hline 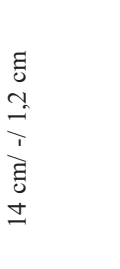 & 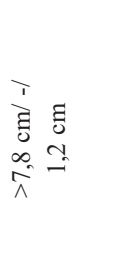 & $\begin{array}{l}\text { चี } \\
0 \\
0 \\
\text { हे } \\
\text { के } \\
\infty \\
\text { हे } \\
\text { = }\end{array}$ & $\frac{1}{1}$ & 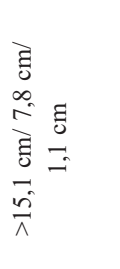 & 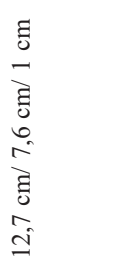 & $\frac{1}{T}$ & 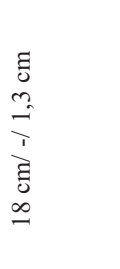 & 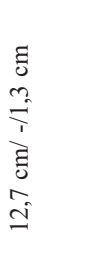 \\
\hline $\begin{array}{l}3 \\
\\
\\
\end{array}$ & $\begin{array}{l}\dot{3} \\
\dot{\Xi} \\
\dot{x}\end{array}$ & $\begin{array}{l}\dot{3} \\
\dot{x} \\
\dot{J}\end{array}$ & 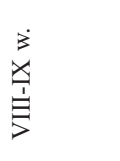 & $\begin{array}{l}\stackrel{3}{3} \\
\stackrel{x}{x} \\
\ddot{u}\end{array}$ & $\begin{array}{l}\ddot{z} \\
\ddot{u}\end{array}$ & 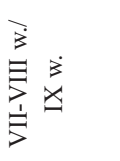 & $\begin{array}{l}\stackrel{3}{3} \\
\stackrel{3}{\prime} \\
\end{array}$ & 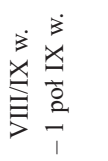 \\
\hline $\begin{array}{l}\text { 莡 } \\
0 \\
0\end{array}$ & 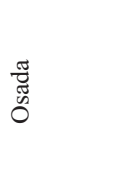 & 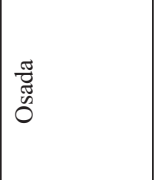 & $\begin{array}{l}\frac{\pi}{\mathscr{J}} \\
0 \\
0\end{array}$ & $\begin{array}{l}\frac{\pi}{\mathscr{J}} \\
0 \\
0\end{array}$ & 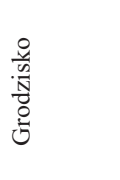 & 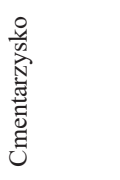 & 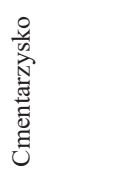 & 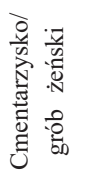 \\
\hline \multirow[t]{2}{*}{ 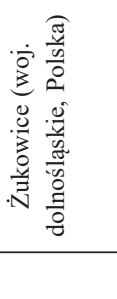 } & 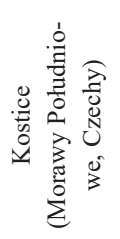 & 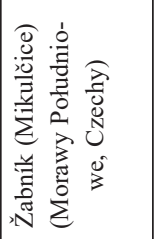 & 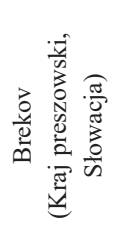 & 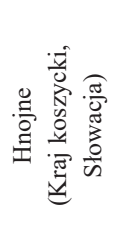 & 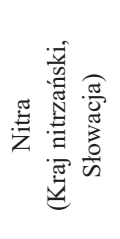 & 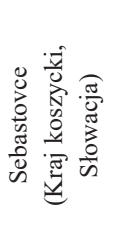 & 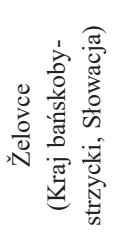 & 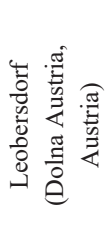 \\
\hline & \multicolumn{8}{|c|}{ Zespół południowy } \\
\hline$\stackrel{0}{-}$ & こ & $\infty$ & 2 & 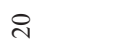 & $\vec{\sim}$ & ป & $\tilde{\imath}$ & $\stackrel{\text { ป }}{ }$ \\
\hline
\end{tabular}




\begin{tabular}{|c|c|c|c|c|c|c|c|}
\hline $\begin{array}{l}\stackrel{\circ}{+} \\
\dot{+} \\
\dot{0}\end{array}$ & $\begin{array}{l}\infty \\
\stackrel{+}{+} \\
\stackrel{0}{:}\end{array}$ & 1 & $\begin{array}{l}\stackrel{\partial}{+} \\
\stackrel{\dot{D}}{\rightleftarrows}\end{array}$ & $\begin{array}{l}\stackrel{\overbrace{}}{+} \\
\dot{0} \\
\dot{Z}\end{array}$ & 1 & $\begin{array}{l}\exists \\
\exists \\
\dot{+} \\
\dot{\partial}\end{array}$ & 1 \\
\hline 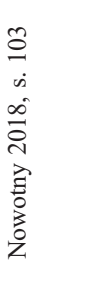 & 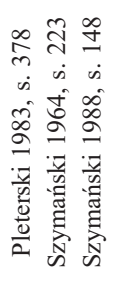 & 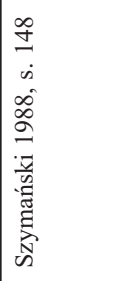 & 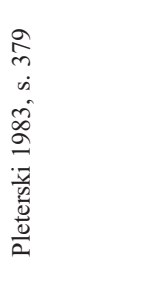 & 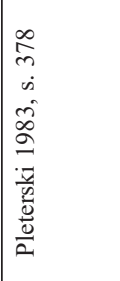 & 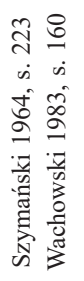 & 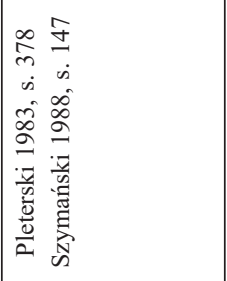 & 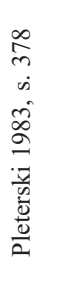 \\
\hline 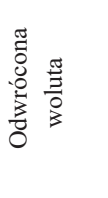 & & & 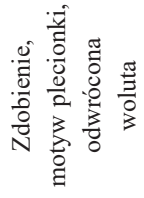 & & & 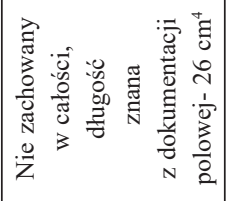 & \\
\hline m & $\vec{s}$ & & ફ) & $\vec{s}$ & & $\vec{s}$ & \\
\hline 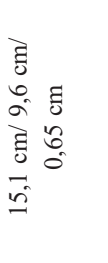 & 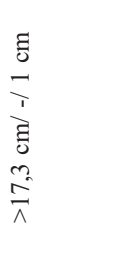 & $\begin{array}{l}\frac{E}{0} \\
\frac{1}{1} \\
\vdots \\
1\end{array}$ & 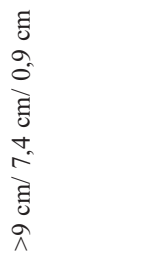 & 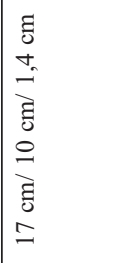 & $\begin{array}{l}1 \\
\text { İ } \\
\text { हे } \\
\text { Е } \\
\text { Е }\end{array}$ & 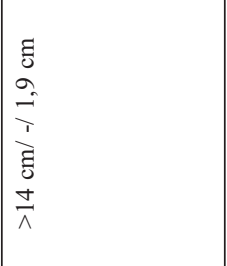 & 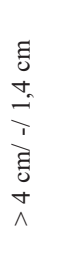 \\
\hline $\begin{array}{l}\stackrel{3}{3} \\
\stackrel{x}{1} \\
\vdots \\
\end{array}$ & 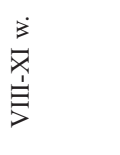 & $\begin{array}{l}\stackrel{3}{3} \\
\stackrel{\Xi}{3} \\
\stackrel{2}{\circ} \\
\stackrel{-}{-}\end{array}$ & $\begin{array}{l}\dot{3} \\
x \\
x\end{array}$ & 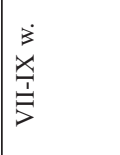 & 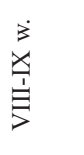 & 离 & $\stackrel{3}{3}$ \\
\hline 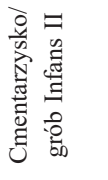 & 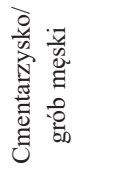 & 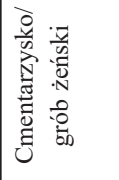 & 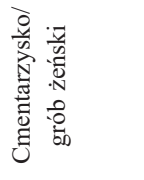 & 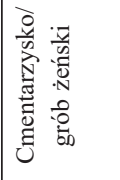 & 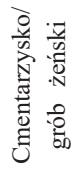 & 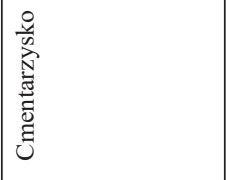 & 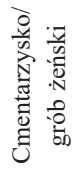 \\
\hline 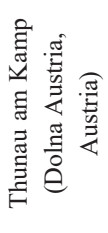 & 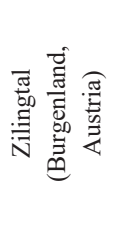 & 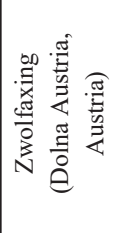 & 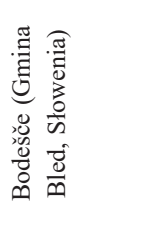 & 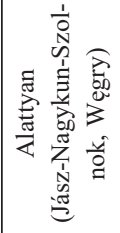 & 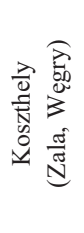 & 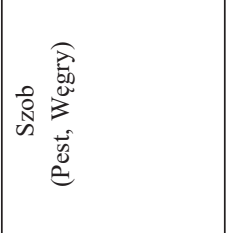 & 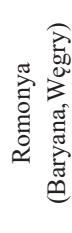 \\
\hline 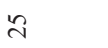 & $\stackrel{\sim}{\sim}$ & $\hat{\sim}$ & $\stackrel{\infty}{\sim}$ & ते & 尺 & $\vec{m}$ & n \\
\hline
\end{tabular}


Noże wolutowe - o funkcji i pochodzeniu zagadkowych przedmiotów...

\begin{tabular}{|c|c|c|c|c|c|c|c|c|}
\hline 1 & $\begin{array}{l}\vec{b} \\
0 \\
0\end{array}$ & 1 & $\begin{array}{l}\tilde{b} \\
0 \\
0\end{array}$ & $\begin{array}{l}3 \\
0 \\
0 \\
0\end{array}$ & $\begin{array}{l}\vec{\sigma} \\
\dot{0} \\
0 \\
0\end{array}$ & $\begin{array}{l}n \\
b \\
0 \\
0\end{array}$ & । & । \\
\hline \multirow[t]{3}{*}{ 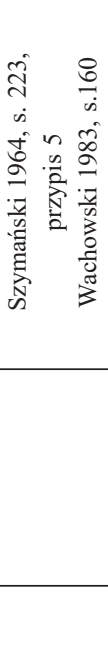 } & 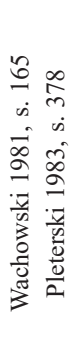 & 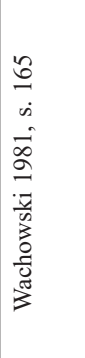 & 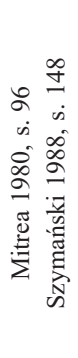 & 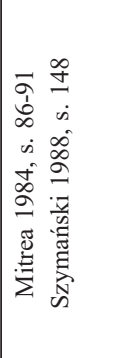 & 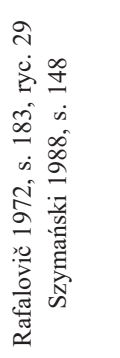 & 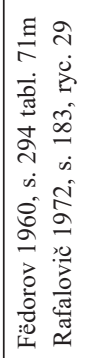 & 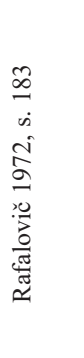 & 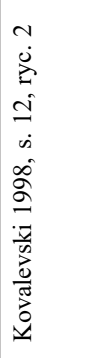 \\
\hline & 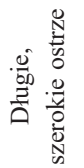 & & & & & 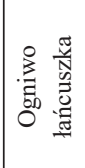 & & \\
\hline & $\underset{\beta}{N}$ & & $\vec{s}$ & $\vec{s}$ & $\vec{s}$ & $\vec{s}$ & & \\
\hline$\frac{1}{T}$ & 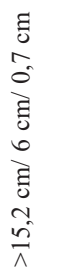 & $\begin{array}{l}E \\
\frac{1}{1} \\
\frac{1}{1}\end{array}$ & 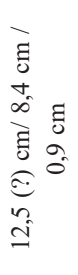 & 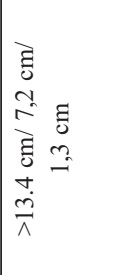 & 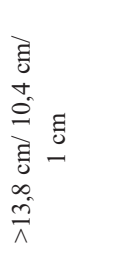 & 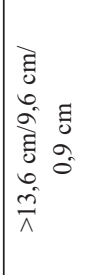 & $\frac{1}{T}$ & $\frac{1}{T}$ \\
\hline 1 & $\dot{3}$ & $\begin{array}{l}3 \\
1=\sqrt{x} \\
\dot{x}\end{array}$ & $\begin{array}{l}\stackrel{3}{3} \\
\stackrel{x}{1} \\
\dot{3}\end{array}$ & 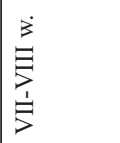 & $\begin{array}{l}\dot{3} \\
\dot{x} \\
\dot{x} \\
\end{array}$ & 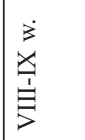 & 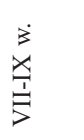 & 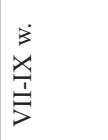 \\
\hline 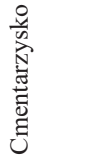 & 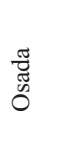 & $\begin{array}{l}\text { 莺 } \\
0\end{array}$ & $\begin{array}{l}\stackrel{\varpi}{\overparen{D}} \\
0 \\
0\end{array}$ & 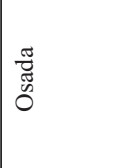 & $\begin{array}{l}\frac{8}{0} \\
\frac{0}{\pi} \\
\frac{\pi}{0} \\
0 \\
0 \\
0\end{array}$ & $\begin{array}{l}\text { 莺 } \\
0 \\
0\end{array}$ & $\begin{array}{l}\stackrel{\pi}{\mathscr{E}} \\
0 \\
0\end{array}$ & । \\
\hline \multirow[t]{2}{*}{ 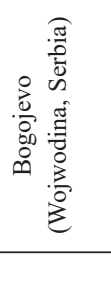 } & 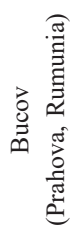 & 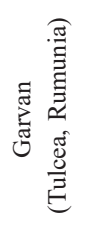 & 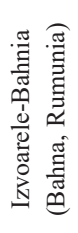 & 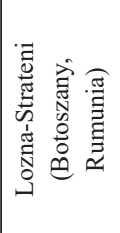 & 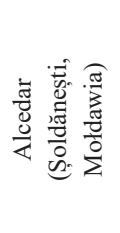 & 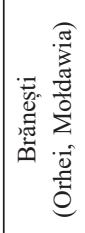 & 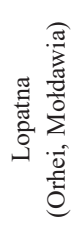 & 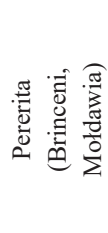 \\
\hline & \multicolumn{8}{|c|}{ Zespół wschodni } \\
\hline$m$ & $\dot{m}$ & $\approx$ & i & $\hat{m}$ & $\infty$ & ले & 우 & $\vec{\gamma}$ \\
\hline
\end{tabular}




\begin{tabular}{|c|c|c|c|c|c|c|c|c|}
\hline $\begin{array}{l}0 \\
\dot{0} \\
\dot{0} \\
:\end{array}$ & । & $\begin{array}{l}\widehat{\sigma} \\
\dot{\Xi} \\
\qquad\end{array}$ & 1 & $\begin{array}{l}\infty \\
\dot{0} \\
\dot{0} \\
\dot{a}\end{array}$ & $\begin{array}{l}\hat{0} \\
\dot{b} \\
\dot{a}\end{array}$ & 1 & $\begin{array}{l}\stackrel{0}{0} \\
\dot{6} \\
\dot{0}\end{array}$ & $\begin{array}{l}= \\
= \\
\dot{0} \\
\dot{0}\end{array}$ \\
\hline 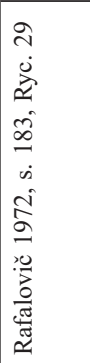 & 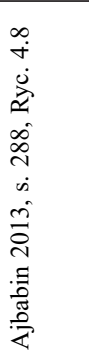 & 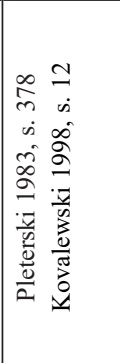 & 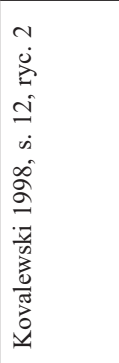 & 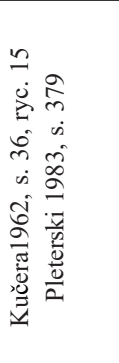 & 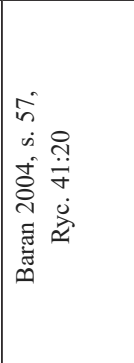 & 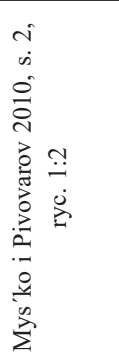 & 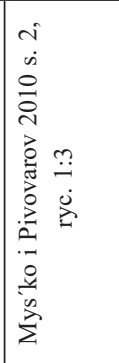 & 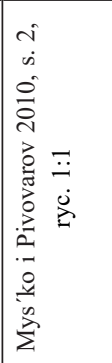 \\
\hline & 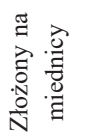 & & & 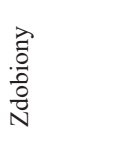 & & & & \\
\hline$\vec{s}$ & & $\vec{s}$ & & $\vec{s}$ & $\vec{s}$ & & $\vec{s}$ & $\vec{s}$ \\
\hline 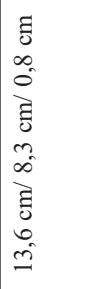 & 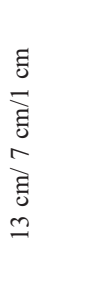 & 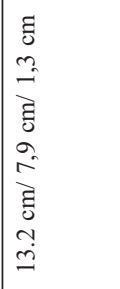 & 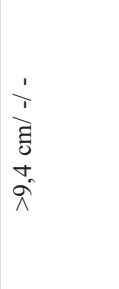 & 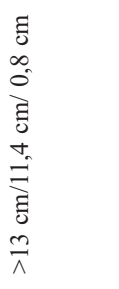 & 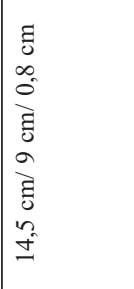 & 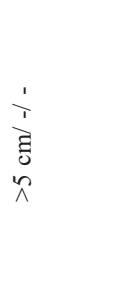 & 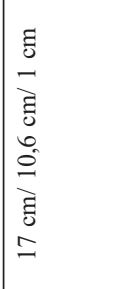 & 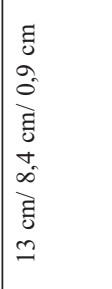 \\
\hline & 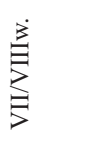 & 萨 & 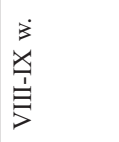 & 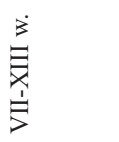 & $\begin{array}{l}\stackrel{3}{凶} \\
凶 \\
凶\end{array}$ & $\ddot{z}$ & $\stackrel{\overrightarrow{3}}{x}$ & 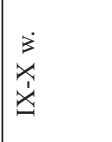 \\
\hline 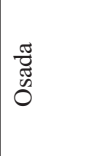 & 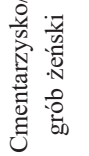 & 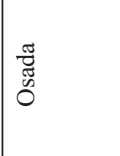 & 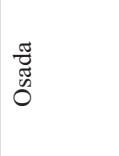 & 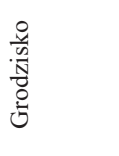 & 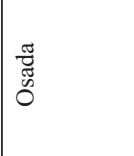 & 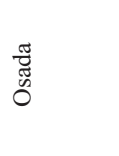 & 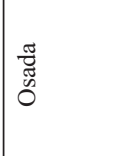 & 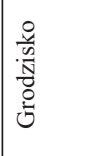 \\
\hline 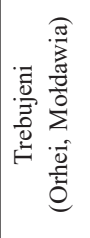 & 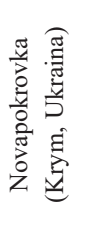 & 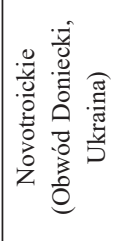 & 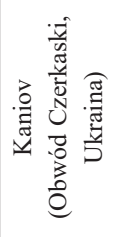 & 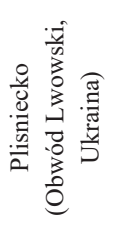 & 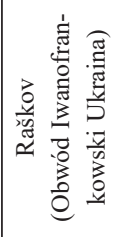 & 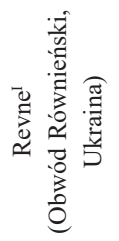 & 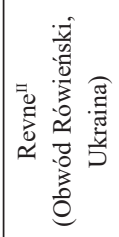 & 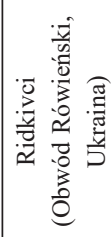 \\
\hline f & $q$ & F & if & f & F & $\stackrel{\infty}{q}$ & gे & in \\
\hline
\end{tabular}


Noże wolutowe - o funkcji i pochodzeniu zagadkowych przedmiotów...

\begin{tabular}{|c|c|c|c|c|c|c|c|}
\hline । & 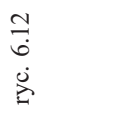 & 1 & 1 & $\begin{array}{l}\vec{T} \\
\stackrel{0}{\overparen{i}}\end{array}$ & 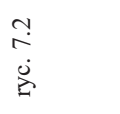 & $\begin{array}{l}? \\
? \\
\stackrel{0}{?}\end{array}$ & 1 \\
\hline 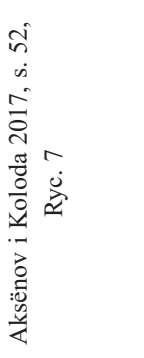 & 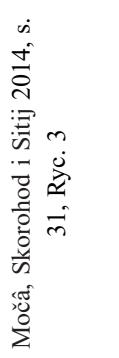 & 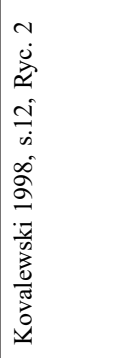 & 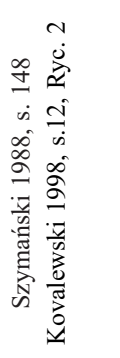 & 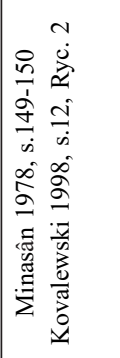 & 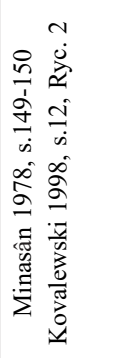 & 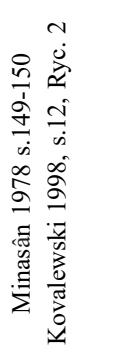 & 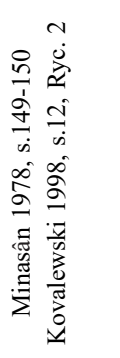 \\
\hline \multirow[t]{2}{*}{ 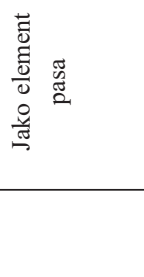 } & & & & & & & \\
\hline & $\vec{s}$ & & & s & 胥 & $\underset{f}{\vec{s}}$ & \\
\hline 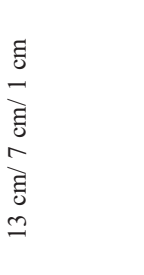 & $\frac{1}{T}$ & 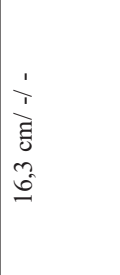 & 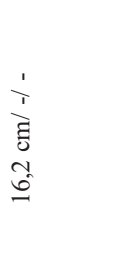 & 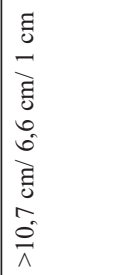 & 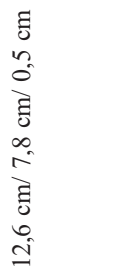 & $\begin{array}{l}\text { ह } \\
\text { aे } \\
\text { हे } \\
\text { aे } \\
\text { हे } \\
\text { ले }\end{array}$ & $\begin{array}{l}1 \\
\text { ì } \\
\text { हे } \\
\hat{\imath}\end{array}$ \\
\hline$\stackrel{3}{\stackrel{B}{\prime}}$ & $\begin{array}{l}\ddot{3} \\
\ddot{x} \\
\ddot{u}\end{array}$ & $\begin{array}{l}\stackrel{3}{x} \\
\dot{x} \\
\ddot{x}\end{array}$ & $\begin{array}{l}\dot{3} \\
\dot{u} \\
\dot{1} \\
\dot{J}\end{array}$ & $\begin{array}{l}\stackrel{3}{B} \\
\end{array}$ & 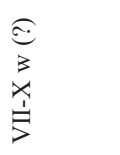 & $\begin{array}{l}\underset{8}{3} \\
\dot{x} \\
\frac{1}{5} \\
\dot{5}\end{array}$ & $\begin{array}{l}\widehat{3} \\
3 \\
x \\
\frac{1}{5} \\
\frac{1}{5}\end{array}$ \\
\hline 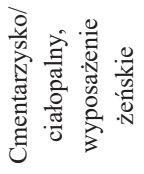 & 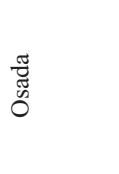 & $\begin{array}{l}\stackrel{\varpi}{\overparen{E}} \\
0 \\
0\end{array}$ & 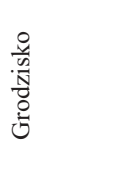 & $\begin{array}{l}\frac{8}{2} \\
\frac{1}{\pi} \\
\frac{\pi}{0} \\
0 \\
0\end{array}$ & 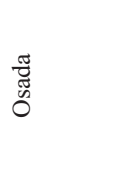 & 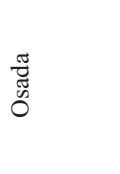 & \begin{tabular}{l} 
胥 \\
\multirow{2}{*}{0}
\end{tabular} \\
\hline \multirow[t]{2}{*}{ 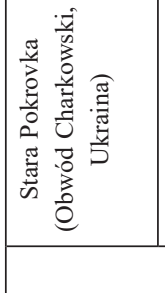 } & 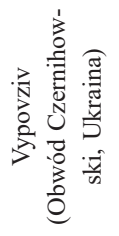 & 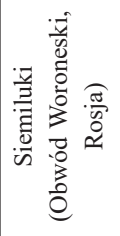 & 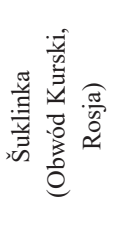 & 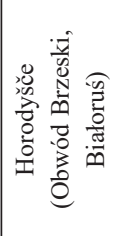 & 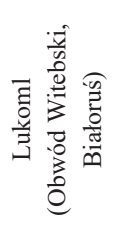 & 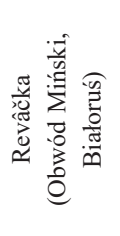 & 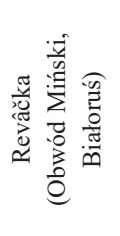 \\
\hline & & & & \multicolumn{4}{|c|}{ Zespół północny } \\
\hline$\vec{n}$ & ก & $n$ & 芯 & $n$ & $\stackrel{\circ}{n}$ & in & $i$ \\
\hline
\end{tabular}




\begin{tabular}{|c|c|c|c|c|c|c|c|c|}
\hline 1 & 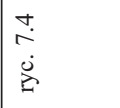 & \begin{tabular}{l}
$n$ \\
$\stackrel{n}{0}$ \\
$\dot{0}$ \\
\multirow{2}{*}{}
\end{tabular} & 1 & 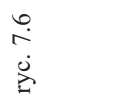 & $\begin{array}{l}\stackrel{i}{\pi} \\
\dot{0}\end{array}$ & $\begin{array}{l}\stackrel{\infty}{\stackrel{0}{0}} \\
\stackrel{0}{ٌ}\end{array}$ & $\begin{array}{l}\text { त) } \\
\dot{0} \\
\dot{Z}\end{array}$ & $\begin{array}{l}+\dot{\infty} \\
\dot{0} \\
\dot{0}\end{array}$ \\
\hline 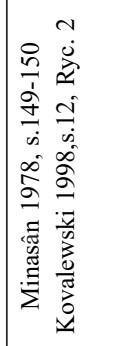 & 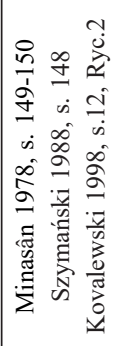 & 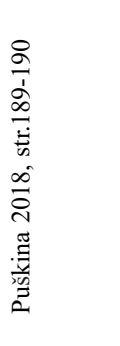 & 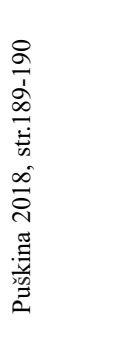 & 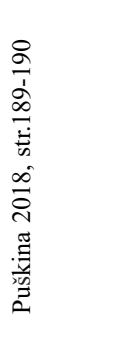 & 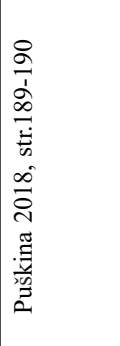 & 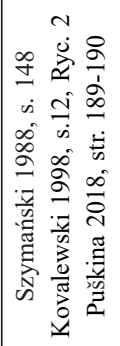 & 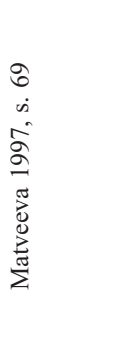 & 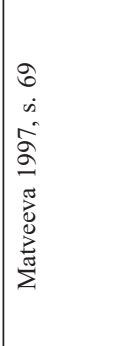 \\
\hline & & & & & $\begin{array}{l}\overrightarrow{0} \\
\text {. } \\
\frac{0}{0} \\
\frac{0}{N}\end{array}$ & & & \\
\hline & $\vec{s}$ & $\stackrel{+}{\stackrel{\nabla}{\Leftrightarrow}}$ & & $\vec{s}$ & $\vec{s}$ & 离 & 1 & 1 \\
\hline$\frac{1}{T}$ & $\begin{array}{l}5 \\
0 \\
n \\
0 \\
\text { हे } \\
0 \\
i \\
\text { हे } \\
0 \\
0\end{array}$ & 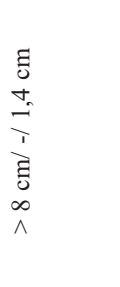 & $\begin{array}{l}\frac{1}{1} \\
\text { हे } \\
\hat{\wedge}\end{array}$ & 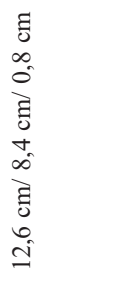 & $\begin{array}{l}\text { चี } \\
\infty \\
0 \\
0 \\
\text { हे } \\
0 \\
0 \\
0 \\
\text { हे } \\
0 \\
0 \\
\dot{0} \\
=\end{array}$ & $\begin{array}{l}1 \\
1 \\
\text { हे } \\
\text { हो } \\
\text { o } \\
\text { in }\end{array}$ & $\frac{1}{T}$ & $\frac{1}{\frac{1}{1}}$ \\
\hline $\begin{array}{l}\dot{3} \\
\dot{\Delta} \\
\dot{J}\end{array}$ & 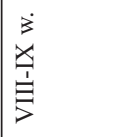 & 1 & 1 & 1 & 1 & $\begin{array}{l}\dot{3} \\
\stackrel{x}{1} \\
\stackrel{B}{J}\end{array}$ & $\frac{3}{3}$ & $\stackrel{3}{3}$ \\
\hline 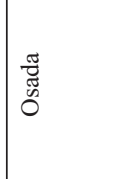 & $\begin{array}{l}\underset{\overparen{J}}{\mathscr{J}} \\
0 \\
O\end{array}$ & $\begin{array}{l}\mathbb{\pi}_{\mathscr{D}} \\
0\end{array}$ & 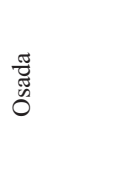 & $\begin{array}{l}\text { 芯 } \\
\text { Ő }\end{array}$ & $\begin{array}{l}\text { 苂 } \\
\text { Ő }\end{array}$ & $\begin{array}{l}\text { 芯 } \\
\text { Ő }\end{array}$ & 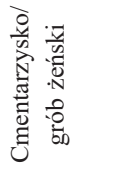 & 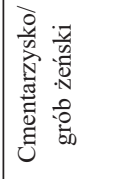 \\
\hline 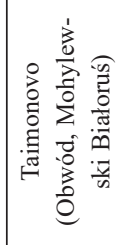 & 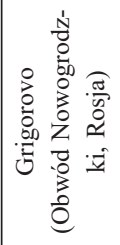 & 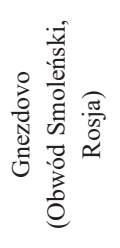 & 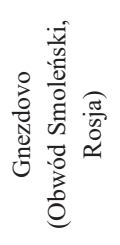 & 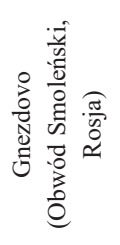 & 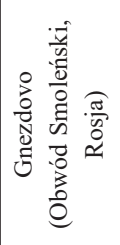 & 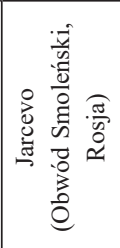 & 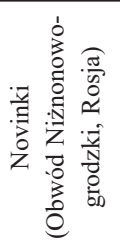 & 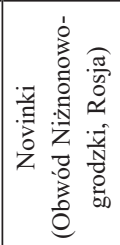 \\
\hline & & & & & & & \multicolumn{2}{|c|}{ Grupa nadwołżańska } \\
\hline in & 8 & $\overrightarrow{6}$ & $\widetilde{\sigma}$ & $\widehat{6}$ & t & 6 & $\stackrel{8}{8}$ & $\hat{\sigma}$ \\
\hline
\end{tabular}


Noże wolutowe - o funkcji i pochodzeniu zagadkowych przedmiotów...

\begin{tabular}{|c|c|c|c|c|c|c|c|c|}
\hline $\begin{array}{l}n \\
\infty \\
\infty \\
\vdots \\
\vdots\end{array}$ & $\begin{array}{l}0 \\
\infty \\
0 \\
0\end{array}$ & $\begin{array}{l}\vec{\infty} \\
\dot{0} \\
0\end{array}$ & 1 & 1 & $\begin{array}{l}3 \\
\infty \\
\dot{1} \\
\dot{a}\end{array}$ & 1 & 1 & 1 \\
\hline \multirow[t]{2}{*}{ 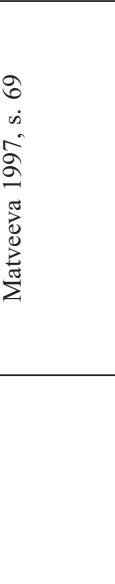 } & \multirow[t]{2}{*}{ 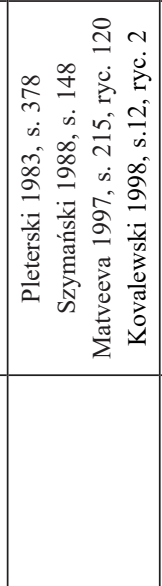 } & \multirow[t]{2}{*}{ 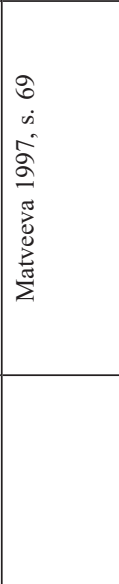 } & \multirow[t]{2}{*}{ 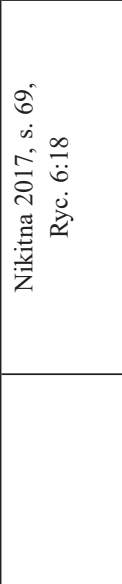 } & \multirow[t]{2}{*}{ 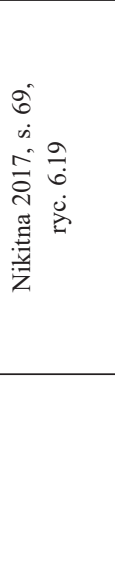 } & \multirow[t]{2}{*}{ 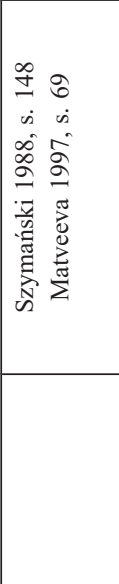 } & 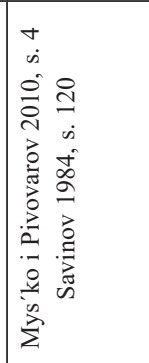 & 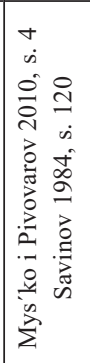 & 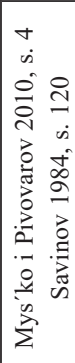 \\
\hline & & & & & & 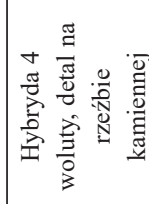 & 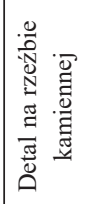 & 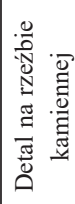 \\
\hline 1 & 1 & 1 & & & 1 & 1 & 1 & 1 \\
\hline$\frac{1}{T}$ & $\begin{array}{l}1 \\
1 \\
\vdots \\
\vdots \\
0 \\
= \\
=\end{array}$ & $\begin{array}{l}\frac{1}{1} \\
\text { हे } \\
\infty \\
\infty \\
-\end{array}$ & $\frac{1}{T}$ & $\frac{1}{T}$ & $\frac{T}{T}$ & $\frac{1}{T}$ & $\frac{1}{T}$ & $\frac{1}{T}$ \\
\hline$\stackrel{3}{\xi}$ & $\begin{array}{l}3 \\
\stackrel{3}{1} \\
\stackrel{3}{y}\end{array}$ & $\stackrel{3}{\xi}$ & $\stackrel{\vec{B}}{\vec{F}}$ & $\stackrel{\vec{E}}{\equiv}$ & $\stackrel{3}{F}$ & 1 & 1 & 1 \\
\hline 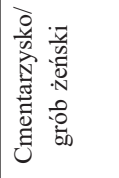 & 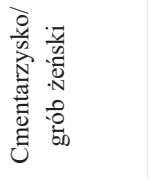 & 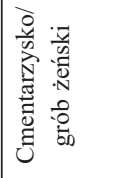 & 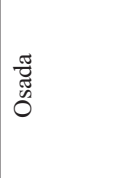 & $\begin{array}{l}\text { 丞 } \\
\text { D. }\end{array}$ & 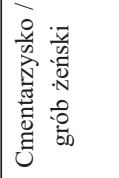 & 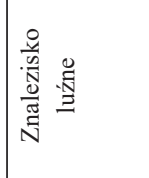 & 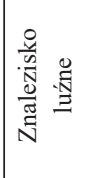 & 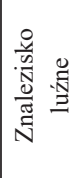 \\
\hline 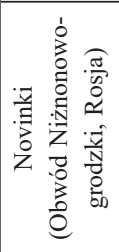 & 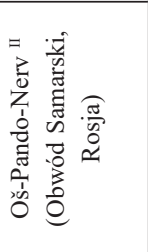 & 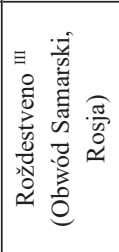 & 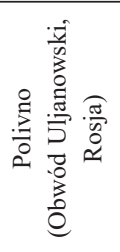 & 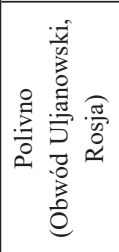 & 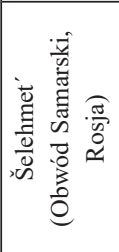 & 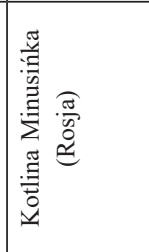 & 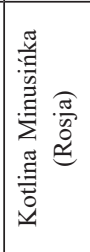 & 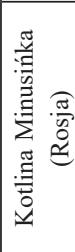 \\
\hline & & & & & & & pa azjaty & \\
\hline$\infty$ & 8 & 尺 & $\approx$ & N & 2 & I & $\approx$ & $\because$ \\
\hline
\end{tabular}




\section{BIBLIOGRAFIA}

Aksënov V.S., Koloda V.V. 2017, Bogatyj veŝevoj kompleks bliz Staroj Pokrovki na Har'kovŝine, „Hazarskij Al'manah", t. 15, s. 37-57.

Ajbabin A.I. 2013, Arheologičskoe nasledie Hazar vremeni sozdaniâ kaganata, „Materialy po archeologii, istorii i ètnografii Tavrii”, wyd. 18, s. 277-315.

Baran J. 2004, Slov 'âns'ka obŝina, Kiïv, Černivci, Zelena Bukovina.

Bartošková A 2007, Výpověd' keramiky z polohy Žabník $k$ vývoji pohřbívání a sídleni v mikulčickém podhradi, "Archeologické rozhledy" 59:4, s. 675-712.

Biermann F. 2001, Pennigsberg. Untersuchungen zu der slawischen Burg bei Mittenwalde und zum Siedlungswesen des 7./8. bis 12. Jahrhunderts am Teltow und im Berliner Raum, "Beiträge zur Urund Frühgeschichte Mitteleuropas" 26, Weissbach, Beier \& Beran.

Biermann F., Frey K. 2000, Neues von einer alten Grabung - der slawische Burgwall Pennigsberg bei Mittenwalde, „Ethnographisch-Archäologische Zeitschrift” 41, s. 199-224.

Biermann F., Kieseler A., Nowakowski D. 2008, Neue Forschungen am Burgwall Kleinitz (Klenica, pow. zielonogórski) in Niederschlesien, Polen. Ein Vorbericht, „Ethnographisch-Archäologische Zeitschrift" 49, s. 67-98,

- 2014, Grodzisko plemienne w Chobieni gm. Rudna w świetle badań archeologicznych 2010 r., w: K. Chrzan, K. Czapla, S. Moździoch (red.), Funkcje grodów w państwach wczesnośredniowiecznej Europy Środkowej. Społeczeństwo, gospodarka, ideologia, Wrocław-Głogów, Instytut Archeologii i Etnologii Polskiej Akademii Nauk, Państwowa Wyższa Szkoła Zawodowa w Głogowie, s. 269-334.

Biermann F., Macháček J., Schopper F. 2015, An Thaya und Notte im Mittelalter: vergleichende archäologische Untersuchungen zu Sozial- und Siedlungsstrukturen im westslawischen Raum (6. bis 13. Jahrhundert), "Studien zur Archäologie Europas", t. 25, Bonn, Habelt Verlag.

Chropovský B. 1978, Významné slovanské náleziská na Slovensku, Bratislava, Veda.

Ciglenečki S. 2000, Tinje nad Loko pri Žusmu. Poznoantična in zgodnjesrednjeveška naselbina, „Opera Instituti Archaeologici Sloveniae" 4, Ljubljana, Založba ZRC.

Daim F. 1987, Das awarische Gräberfeld von Leobersdorf, Niederösterreich, Wien, Verlag der österreichischen Akademie der Wissenschaften.

Dulnicz M. 1994, Problem datowania grodzisk typu Tornow i grupy Tornow: Klenica, „Archeologia Polski", t. 39:1, s. 31-47.

- 2003, „Pennigsberg - Untersuchungen zu der slawischen Burg bei Mittenwalde und zum, Siedlungswesen des. 7 /8. bis 12. Jahrhunderts am Teltow und im Berliner Raum, F. Biermann (red.), Weissbach 2001 [recenzja], "Przegląd Archeologiczny", t. 51, s. 198-205.

Fëdorov G. 1960, Naselenie Prutsko-Dnestrovskogo meždureč'â v 1 tysâčeletii n.è., Materialy i issledovaniâ po arheologii SSSR, t. 89, Moskva, Izdatel'stvo Akademii Nauk SSSR.

Hachulska-Ledwos R. 1971, Wczesnośredniowieczna osada w Nowej Hucie-Mogile, „Materiały Archeologiczne Nowej Huty", t. 3, s. 7-210.

Gardawski A. 1951, Noże kultury wenedzkiej z cmentarzyska w miejscowości Gledzianówek, pow. Łęczyca i z Biskupina, „Sprawozdania Państwowego Muzeum Archeologicznego”, t. 4, z. 3/4 s. 127-138.

Ginalski J., Muzyczuk A. 1989, Wyniki badań wykopaliskowych na grodzisku wczesnośredniowiecznym w Brzezowej, gmina Nowy Żmigród, województwo krośnieńskie, „Acta Archeologica Carpathica”, t. 27 , s. $217-230$.

Hampel J. 1905, Alterthumer des frühen Mittelalters in Ungarn, Brunsweig.

Hošek J., Profantovă N., Šilhová A., Ottenwelter E. 2007, Bohemian so-called surgical early medieval knives, "Acta Metallurgica Slovaka", t. 13, s. 932-937.

Jaworski K. 2005, Grody w Sudetach (VIII-X w.), Wrocław, Uniwersytet Wrocławski. Instytut Archeologii.

Jażdżewski K. 1960, Wzajemny stosunek elementów stowiańskich i germańskich w Europie środkowej $w$ czasie od najścia Hunów aż do usadowienia się Awarów nad środkowym Dunajem, Prace i materiały Muzeum Archeologicznego i Etnograficznego w Łodzi (seria archeologiczna), nr 5, s. 51-77. 
Kaczkowski M. 1971, Charakterystyka osadnictwa wczesnośredniowiecznego w rejonie Głogowa od połowy V do połowy XI w. w świetle źródeł archeologicznych, ,Zielonogórskie Zeszyty Muzealne”, t. 2, s. 5-37.

Kara M. 2009, Najstarsze państwo Piastów-rezultat przełomu czy kontynuacji? Studium archeologiczne, Poznań.

Kara M., Makohonienko M., Michałowski A. 2016, Poznań na tle wczesnośredniowiecznego osadnictwa grodowego obszaru Wielkopolski w kontekście uwarunkowań środowiskowych - studium geoinformacyjne, w: Przemiany osadnictwa i środowiska przyrodniczego Poznania i okolic od schytku starożytności do lokacji miasta, Poznań, Bogucki Wydawnictwo Naukowe, s. 213-245.

Kara M., Przybył M. 2003, Wczesnośredniowieczne grodzisko wklęsłe w Bninie koło Poznania w świetle dotychczasowych ustaleń dendrochronologicznych, Folia Praehistorica Posnaniensia 10/11, s. 255-268.

Knific T., Pleterski A. 1981, Staroslovansko grobišče Dlesc pri Bodeščah, „Arheološki vestnik” 32, s. $482-523$.

Kobusiewicz M. 2008, Pradzieje Wielkopolski. Od epoki kamienia do średniowiecza, Poznań, Instytut Archeologii i Etnologii Polskiej Akademii Nauk.

Kolenda J. 2008, Milicz - clavis Regni Poloniae: gród na pograniczu, Wrocław, Instytut Archeologii i Etnologii Polskiej Akademii Nauk.

Korol'kova L. 1994, Voprosy interpretačii nožej s volûtoobraznym naweršiem, Twerskoj arheologičeskij sbornik, wyd. 1, s. 234-238.

Kovaleski V. 1998, Eŝe raz o nožah s volûtoobraznym naveršiem, Voprosy istorii slavân. Arheologiâ. Ètnografiâ, vol. 12, s. 9-24.

Kučera M. 1962, Drevniìj Plisnes'k, Arheologični Pam'âtki URSR t. 12, s. 3- 55.

Lodowski J. 1966, Nóż-sztylecik z wolutowym zakończeniem rękojeści z Czeladzi Wielkiej, pow. Góra, „Silesia Antiqua” 8, s. 104-109.

Matveeva G. 1997, Mogil'niki rannih bolgar na Samarskoj Luke, Samara, Samarskij Universitet.

Mihajlina L. 2007, Slov'âni VII-X st. miž Dniprom i Karpatami, Kï̈v, Institut arheologiï Načional'noï Akademiï Nauk Ukraïni.

Minasân R. 1978, Železnye nožy s volûtoobraznym naveršiem, „Problemy Arheologii”, t. 2, s. 148-152.

Mitrea I. 1980, Regiunea centrala a Moldovei dintre Carpati si Siret in secolele VI-IX e.n., „Carpica”, t. 12 , s. $55-191$.

- 1984, Unele consideratii privind originea, cronologia si semnificatia etno-culturala a cutitelor cu volute descoperite po teritoriul Romaniei, „Carpatica”, t. 16, s. 85-93.

Močâ O.P., Skorohod V.M., Sitij Û.M. 2014, Vipovzìvs'kij arheologičnij kompleks u svitli novih doslidžen' 2009-2013 rr., w: P. Toločko (red.), Mista Da'vnoï Rusi: Zbirka naukovyh prač' pam 'âti A.V. Kuzy, Kiïv, Institut arheologiï Načional'noï Akademiï Nauk Ukraïni, s. 26-78.

Moździoch S. 2011, Czy monarchia pierwszych Piastów była państwem chrześcijańskim? Uwagi archeologa, w: T. Grabarczyk, T. Nowak (red.), Dynamika przemian społecznych i religijnych $w$ średniowieczu, Warszawa, DiG.

Muzolf B. 1994, Wielokulturowe stanowisko archeologiczne na Górze Birów w Podzamczu, województwo katowickie. Sezon III - 1992 r., w: E. Tomczak (red.), Badania archeologiczne na Górnym Śląsku i $w$ Zagłębiu Dąbrowskim w latach 1991-1992, Katowice, Centrum Dziedzictwa Kulturowego Górnego Śląska, s. 259-270.

Muzyczuk A., Ginalski J. 1992, Badania wykopaliskowe grodziska wczesnośredniowiecznego w Brzezowej, gm. Nowy Żmigród, woj. krośnieńskie, w: Materiały i Sprawozdania Rzeszowskiego Ośrodka Archeologicznego, t. 1985-1990, s. 209-217.

Mys'ko J. 2012, The religious beliefs of Slav population in the Upper Prut and the Middle Dniester region, w: M. Salamon (red.), Rome, Constantinople and Newly Converted Europe Archaeological and Historical Evidence, t. 1, cz. 2, Kraków-Leipzig-Rzeszów-Warszawa, Geisteswissenschaftliches Zentrum Geschichte und Kultur Ostmitteleuropas, Instytut Archeologii i Etnologii Państwowej Akademii Nauk, Instytut Archeologii Uniwersytetu Rzeszowskiego, s. 545-561.

Mys'ko J. i Pivovarov S. 2010, Finds of Knives with Curls on the Handles in the Region of the Upper Prut and the Middle Dniester, "Stratum plus", t. 5, s. 309-317. 
Nikitina A. 2017, Nekotorye slučajnye nahodki èpohi Velikogo pereseleniâ narodov i rannego sredenivekov'â Ul'ânovskogo regiona. Voâdžer: mir i čelovek: teoretyčeskij i naučno-metodičeskij žurnal. $\mathrm{Nr}$ 8, Samara, Samarskij Gosudarstvennyj Tehničeskij Universitet.

Nowotny E. 2018, Thunau am Kamp - Das frühmittelalterliche Gräberfeld auf der Oberen Holzwiese, Wien, Austrian Academy of Sciences Press.

Parczewski M. 1989, Żukowice pod Głogowem w zaraniu średniowiecza, „Głogowskie Zeszyty Naukowe" 2, Głogów, Dolnośląskie Towarzystwo Społeczno-Kulturalne.

Pleterski A. 1983, Nožiči z zavojkoma v zgodnjem srednjem veku, „Arheološki vestnik”, t. 34, s. 375-395. Poleski J. 2004, Wczesnośredniowieczne grody w dorzeczu Dunajca, Kraków, Księgarnia Akademicka.

Puškina T.A. 2018, Noži redkoj formy iz Gnëzdova, w: W. Singh (red.), Neskončaemoe Leto- Sbornik statej v čest'Eleny Aleksandrovny Rybinoj, Moskva-Velkij Novgorod, Novgorodskij gosidarswennyj muzej-zapovednik, s. 189-192.

Rabinovič R. 2005, Noži s volûtoobraznymi rukoâtkami na territorii Moldovy i ih kul'turno-istoričeskij kontekst, Revista arheologicä. Serie noua. Vol. 1. Nr. 2, s. 351-359.

Rafalovič A. 1972, Slavâne VI- IX vekov v Moldawii, Kišinev, Štiinča.

Savinov R. 1984, Sibirskie realii polovečkih kamennyh izwaânij, „Arheologiâ ûga Sibiri i Dal'nego Vostoka", s. 115-122.

Šiška S. 1964, Noze s volútovym ukoncenim rukováti v Hradistnej kultúre, „Arckeologické rozhledy” XVI:3, s. 395-404.

Szymański W. 1964, Przyczynki do zagadnienia chronologii i zasięgu występowania żelaznych noży z rękojeściami zakończonymi wolutami, „Wiadomości Archeologiczne”, t. 30, s. 221-228.

- 1988, Noże z rękojeściami zakończonymi wolutami - zagadkowe komponenty kultury słowiańskiej i awarskiej, w: G. Labuda, S. Tabaczyński (red.), Studia nad etnogeneza Stowian, t. 2, Warszawa, Zakład Narodowy imienia Ossolińskich, s. 141-159.

Wachowski K. 1981, Ziemie Polskie a Wielkie Morawy. Studium archeologiczne kontaktów w zakresie kultury materialnej, ,,Przegląd Archeologiczny”, t. 29, s. 151-191.

- 1992, Ziemie Polskie a Wielkie Morawy. Problemy kontaktów ideologicznych i politycznych w świetle archeologii, ,Przegląd Archeologiczny”, t. 30, s. 141-185.

Wakarelski Ch. 1965, Etnografia Bułgarii, Wrocław, Polskie Towarzystwo Ludoznawcze.

Źródła internetowe:

https://auction.catawiki.com/kavels/18404209-medieval-medical-instrument-scalpel-lancet-rare-150-mm [dostęp: 16.05.2020]. 